\title{
Exploring the role of mantle eclogite at mid-ocean ridges and hotspots: U-series constraints on Jan Mayen Island and the Kolbeinsey Ridge
}

\author{
L.J. Elkins ${ }^{1}{ }^{*}$, S.R. Scott ${ }^{2}$, K.W.W. Sims ${ }^{2}$, E.R. Rivers ${ }^{1}$, C.W. Devey ${ }^{3}$, M. Reagan ${ }^{4}$, C. Hamelin ${ }^{5}$, \\ R. Pedersen ${ }^{5}$ \\ 1 Department of Geology, Bryn Mawr College, Bryn Mawr, PA, USA 19010 \\ 2 Department of Geology and Geophysics, University of Wyoming, Laramie, WY, USA 82071 \\ ${ }^{3}$ GEOMAR - Helmholtz Centre for Ocean Research Kiel, Wischhofstrasse 1-3, 24148 Kiel, \\ Germany \\ ${ }^{4}$ Department of Earth and Environmental Sciences, University of Iowa, Iowa City, IA, USA \\ 52242 \\ ${ }^{5}$ Centre for Geobiology, University of Bergen, N-5007 Bergen, Norway \\ * 304 Bessey Hall, Department of Earth and Atmospheric Sciences, University of Nebraska- \\ Lincoln, Lincoln, NE 68588-0340; lelkins@unl.edu, +1 402472 7563, +1 4024724917 (fax)
}

For submission to Chemical Geology. 


\begin{abstract}
Sensitivity to rates of melting and to the presence of garnet in the melting residue makes U-series isotope disequilibrium a helpful tool for assessing the presence and role of mantle eclogite rocks in generating magmatic crust at both mid-ocean ridges and hotspots. Here we present ${ }^{238} \mathrm{U}_{-}{ }^{234} \mathrm{U}-$ ${ }^{230} \mathrm{Th}-{ }^{226} \mathrm{Ra}-{ }^{210} \mathrm{~Pb}$ isotope disequilibria data for a suite of fresh lavas from the tectonically and geochemically complex Jan Mayen region, including Jan Mayen Island; the Northern Kolbeinsey Ridge, which hosts the anomalous Eggvin Bank bathymetric high; and the Southern Mohns Ridge. Age-constrained, unaltered samples from the Northern Kolbeinsey Ridge and Eggvin Bank, including fresh popping rocks from Eggvin Bank, are characterized by relatively high $\left({ }^{230} \mathrm{Th} /{ }^{238} \mathrm{U}\right)=1.23$ to 1.36 and low $\left({ }^{226} \mathrm{Ra} /{ }^{230} \mathrm{Th}\right)=1.24$ to 1.28 . These data are best explained by contributions to magma mixtures from an eclogite-dominated, upwelling mantle source with only modest aging or crystal fractionation effects during transport or storage in the crust. Young lavas from Jan Mayen Island have lower $\left({ }^{230} \mathrm{Th} /{ }^{238} \mathrm{U}\right)=1.15$ and $\left({ }^{226} \mathrm{Ra} /{ }^{230} \mathrm{Th}\right)=1.05$ to 1.16 , and forward modeling suggests a detectible, but smaller mafic source contribution to a peridotitic magma mixture in faster upwelling mantle. Globally, most ocean island basalts also show low $\left({ }^{226} \mathrm{Ra} /{ }^{230} \mathrm{Th}\right)$ disequilibria, suggesting that in addition to high upwelling rates, mafic lithologies make significant melt contributions at most hotspots and that upwelling mantle plumes likely entrain highly fusible, recycled mafic rocks. Eggvin Bank apparently overlies a highly unusual mantle source that likely contains a remnant of delaminated, formerly underplated, ancient subcratonic mafic rocks, entrained by upwelling beneath the northernmost Kolbeinsey Ridge. Keywords: Jan Mayen; Kolbeinsey Ridge; Eclogite; Radium; Uranium; Thorium
\end{abstract}




\section{INTRODUCTION}

The global upper mantle is widely considered to dominantly comprise ultramafic spinel and garnet lherzolites, but the presence of minor quantities ( $\sim 5 \%)$ of mafic lithologies derived from the subducted remains of ancient ocean crust is broadly accepted (e.g., Allègre et al., 1984; Hirschmann and Stolper, 1996). The importance of these mafic components for magma generation at mid-ocean ridges and hotspots is, however, unclear (e.g., Allègre et al., 1984; Chabaux and Allegre, 1994; Donnelly et al., 2004; Hauri, 1996; Hirschmann and Stolper, 1996; Hirschmann et al., 2003; Kogiso and Hirschmann, 2001; Kogiso et al., 2003; 2004; Langmuir et al., 1992; Lassiter et al., 2000; Lundstrom et al., 1999; Niu and Batiza, 1993; 1997; Niu et al., 2001; Pertermann and Hirschmann, 2003a; Russo et al., 2009; Shen and Forsyth, 1995; Sigmarsson et al., 1998; Sims et al., 1999; 2002; Sobolev, 2000; Stracke et al., 1999; 2006; Turner et al., 2015; Waters et al., 2011; Workman et al., 2006). The detection of mafic eclogite and pyroxenite rocks in the mantle using the geochemistry of erupted basalts can be hindered by ambiguous chemical and isotopic signals (e.g., Hirschmann and Stolper, 1996) - neither the presence of garnet in the residuum nor a particular isotopic or trace-element signature of crustal recycling in the source is necessarily unique. A combination of methods that considers multiple factors (such as indicators of melting rate), however, can help to identify lithologically heterogeneous mantle sources (e.g., Elkins et al., 2011; 2014; Prytulak and Elliott, 2009; Sims et al., 2013a; Turner et al., 2015; Waters et al., 2011; 2013a); using major and trace elements, radiogenic isotopes, and U-series is one such useful approach. Experimental results and geochemical models demonstrate that eclogite and pyroxenite rocks are highly fusible, with a narrower melting interval and higher melt productivity than peridotites; such properties translate into higher melting rates and degrees of melting for mafic lithologies than would be expected in 
a peridotite source, for similar temperature conditions and upwelling rates (e.g., Asimow et al., 2001; Elkins et al., 2008; Hirschmann and Stolper, 1996; Hirschmann et al., 2003; Ito and Mahoney, 2005a; Ito and Mahoney, 2005b; Kogiso et al., 2003; Kogiso et al., 2004; Maclennan et al., 2002; Pertermann and Hirschmann, 2003a; Prytulak and Elliott, 2009; Shorttle and Maclennan, 2011; Sims et al., 2013; Turner et al., 2015; Waters et al., 2011). Uranium-series disequilibria in basalts are sensitive to such melting variations.

The Jan Mayen region in the North Atlantic presents an ideal natural laboratory for further investigation of the role of mafic rocks in the generation of magma at both mid-ocean ridges and volcanic hotspots (Fig. 1). Previous work revealed a complex local melting regime, where both the Jan Mayen Island hotspot and the adjacent Mohns Ridge spreading center are likely fed by a small mantle plume with a radiating geochemical signature, and where the adjacent Kolbeinsey Ridge may likewise be influenced by regionally increased mantle temperatures (Blichert-Toft et al., 2005; Debaille et al., 2009; Elkins et al., 2011; 2014; 2016; Schilling et al., 1999; Trønnes et al., 1999). Recently published geochemical data further support the presence of eclogitic mafic rocks in both the Jan Mayen mantle source and beneath the nearby Kolbeinsey Ridge (which overlies a unique mantle source; Elkins et al., 2016). Uraniumseries analytical data are useful for distinguishing between two primary processes for enhanced melt generation in a hotspot-ridge setting such as is found near Jan Mayen: 1) accelerated, "active" upwelling in a mantle plume, resulting in rapid melting rates that initiate in the garnet peridotite stability field; vs. 2) slower, "passive" upwelling beneath a mid-ocean ridge, but with the presence of more fusible mafic rocks in the melt source leading to enhanced melting rates. Here we present ${ }^{238} \mathrm{U}_{-}{ }^{234} \mathrm{U}_{-}{ }^{230} \mathrm{Th}_{-}{ }^{226} \mathrm{Ra}_{-}{ }^{210} \mathrm{~Pb}$ disequilibrium measurements for a suite of fresh, young, volcanic rocks from the Northern Kolbeinsey Ridge (NKR) segment, the Southern 
Mohns Ridge (SMR) segment, and Jan Mayen Island (Fig. 1, Table 1), previously analyzed for major element, trace element, and radiogenic isotopes (Elkins et al., 2016), and interpret the results using time-dependent melting models to better constrain the local and global importance of mafic mantle source rocks on ocean crust genesis.

\section{GEOLOGIC SETTING}

\subsection{Regional tectonic history, morphology, and geophysical constraints}

Jan Mayen Island is located immediately southwest of the intersection of the Mohns Ridge and the Jan Mayen Fracture Zone $\left(71^{\circ} \mathrm{N}, 8.5^{\circ} \mathrm{W}\right)$ and represents the highest elevation along the N-S trending Jan Mayen Ridge (Figure 1). The island is volcanically active with two major volcanic complexes (the basaltic Beerenberg volcano, which has erupted historically, and the older Sor-Jan pyroclastic and lava dome complex in the south) and hosts potassic trachybasaltic rocks that range from ankaramite to trachyte (Imsland, 1986; Maaløe et al., 1986; Thy et al., 1991; Trønnes et al., 1999).

The island is centrally located within the Norwegian-Greenland Sea, which initiated with rifting between Greenland and Eurasia at 53-55 Ma. The early stages of this rifting event produced the Aegir, Mohns, and Gakkel Ridges (Blichert-Toft et al., 2005; Glebovsky et al., 2006; Schilling et al., 1999; Shipilov, 2008). Approximately $~ 10$ Ma later, the rift axis of the new Kolbeinsey Ridge began propagating northward, contemporaneous with waning Aegir Ridge spreading; the axial relocation to the Kolbeinsey Ridge concluded when rifting ceased on the Aegir Ridge at $\sim 26$ Ma. This ridge jump probably detached a continental fragment from Greenland to produce the Jan Mayen Ridge (Gaina et al., 2009; Johnson and Heezen, 1967; Kodaira et al., 1997); this is supported by seismic velocity measurements which show 
continental values over the Ridge (Breivik et al., 2009). Immediately following the ridge jump, the overall spreading direction of the Mohns Ridge changed from NNW-SSE to the more oblique NW-SE (Mjelde et al., 2008). To the west of Jan Mayen, the modern Kolbeinsey Ridge spreads orthogonally at ultraslow rates (18 mm/yr. full spreading rate) (Breivik et al., 2006; Mosar et al., 2002), terminating to the north at the Jan Mayen Fracture Zone $\left(71.5^{\circ} \mathrm{N}\right)$. Despite its ultraslow spreading rate, the Kolbeinsey Ridge is volcanically active along its entire length and hosts a vigorous neovolcanic zone. The ridge contains two small offsets: the Spar Fracture Zone at $69.1^{\circ} \mathrm{N}$ and an overlapping spreading center at $70.7^{\circ} \mathrm{N}$ (Haase et al., 2003), which subdivide the ridge into Southern, Middle, and Northern second-order ridge segments. The northernmost of these, the NKR, includes the Eggvin Bank, an anomalously shallow, central bathymetric high (Brandsdottir et al., 2004; Elkins et al., 2016; Hooft et al., 2006; Yeo et al., 2016).

New multibeam bathymetric mapping from the 2012 POS-436 cruise of R/V Poseidon to the NKR (Devey, 2012) allowed several key bathymetric features to be identified (see Fig. 1 and Devey, 2012; Elkins et al., 2016; Yeo et al., 2016). In addition to the anomalously large depth differences between the deeper northern and southern ends of the segment axis and the shallow, central Eggvin Bank, there is substantial morphologic evidence for enhanced magma flux to the central ridge axis. Specifically, there is a visible transition in volcanic character from dominantly monogenetic, flat-topped volcanoes at the segment ends to larger sheet flows towards the center of the segment, and a large volcanic edifice positioned astride the eastern axial flank wall. This large conical seamount rises to $28 \mathrm{~m}$ depth, hosts a steep-walled summit crater from which fresh popping rocks were retrieved (Devey, 2012), and is covered in fresh, basaltic flank eruptions. In the southern part of the segment, two parallel neovolcanic zones hosting recent lavas were identified, suggesting either active relocation of the ridge axis or doubly active axes in the 
southern portion of the NKR segment. This morphology notably resembles the Icelandic neovolcanic rift zone in overall geometry, albeit on a significantly reduced spatial scale (Elkins et al., 2016; Yeo et al., 2016).

Spreading continues north of the Jan Mayen Fracture Zone along the ultraslow-spreading Mohns Ridge (17 mm/yr. full spreading rate) (Mosar et al., 2002). The Mohns Ridge is considerably deeper than the Kolbeinsey Ridge and is thought to overlie thinner crust (4 to $8 \mathrm{~km}$ ) (Kandilarov et al., 2008; Klingelhofer et al., 2000; Ljones et al., 2004; Okino et al., 2002); plate motion is generally highly oblique to the NE-SW morphological trend of the ridge valley (Okino et al., 2002) (Fig. 1). In contrast to this regional morphology, a small, second-order segment (the SMR) immediately north of the Fracture Zone shows a nearly-orthogonal axial valley. While overall deeper than the NKR and hosting on average more altered and therefore likely older volcanic rocks (Elkins et al., 2016), the SMR is nonetheless shallower than the rest of the Mohns Ridge, suggesting thicker ocean crust than along the ridge to the north. Pedersen et al. (2010) presented preliminary high-resolution multibeam bathymetry for the SMR and observed anomalously large volcanic features, including a possible caldera structure off-axis, and a large volcanic edifice that has been bisected by the axial rift. Although the latter two structures are not as large as the Eggvin Bank seamount, the presence of large volcanic structures along both segments is noteworthy.

\subsection{Jan Mayen geochemistry}

\subsubsection{Working hypotheses for the origins of anomalous Jan Mayen volcanism}

A number of contradictory scenarios have been proposed to explain the anomalous volcanic activity in the Jan Mayen region, without a general consensus. In their early work on 
North Atlantic volcanism, Neumann and Schilling (1984) and Schilling et al. (1999) observed increases in trace element and isotopic enrichment with proximity to the Jan Mayen Fracture Zone along the NKR (where "enrichment" refers to relatively high concentrations of incompatible trace elements, elevated ${ }^{87} \mathrm{Sr} /{ }^{86} \mathrm{Sr},{ }^{206} \mathrm{~Pb} /{ }^{204} \mathrm{~Pb},{ }^{207} \mathrm{~Pb} /{ }^{204} \mathrm{~Pb}$, and ${ }^{208} \mathrm{~Pb} /{ }^{204} \mathrm{~Pb}$ ratios, and relatively unradiogenic $\varepsilon_{\mathrm{Nd}}$ ). They postulated that volcanism at Jan Mayen is fed by a mantle plume, one with relatively low ${ }^{3} \mathrm{He} /{ }^{4} \mathrm{He}$ and mantle-like $\mathrm{Ce} / \mathrm{Pb}$ and $\mathrm{Nb} / \mathrm{U}$ (Hanan et al., 2000; Neumann and Schilling, 1984; Schilling et al., 1999).

Additional work posited that a discrete plume source may not be necessary to explain Jan Mayen Island hotspot volcanism and nearby MORB geochemistry (e.g., Haase et al., 1996; 2003; Mertz and Haase, 2003; Mertz et al., 2004; Trønnes et al., 1999). The absence of a distinct local plume would suggest that Jan Mayen's volcanic activity and relatively enriched geochemical signatures may instead derive from a heterogeneous mantle source, perhaps combined with unusual local mantle flow dynamics and preferential sampling of enriched material resulting from locally wetter mantle (Blichert-Toft et al., 2005; Debaille et al., 2009; Haase et al., 1996; 2003; Mertz and Haase, 1997; Mertz et al., 2004; Trønnes et al., 1999). Such mantle heterogeneities could contain material from the Iceland mantle plume head, emplaced in the early Tertiary (Debaille et al., 2009; Mertz et al., 2004; Trønnes et al., 1999) as well as continental or subcontinental lithospheric material entrained during the opening of the Greenland basin and subsequent Aegir-Kolbeinsey axial relocation (Blichert-Toft et al., 2005; Debaille et al., 2009; Haase et al., 1996; 2003; Mertz and Haase, 1997; Mertz et al., 2004; Trønnes et al., 1999). High precision $\mathrm{Nd}-\mathrm{Hf}-\mathrm{Pb}$ radiogenic isotopic analyses of MORB (Blichert-Toft et al., 2005) further prompted the hypothesis that the Jan Mayen Fracture Zone overlies an important chemical boundary in the mantle, separating two distinct mantle reservoirs. 


\subsubsection{Unresolved Jan Mayen questions}

Analyses of major element, trace element, and long-lived radiogenic isotope compositions for the same suite of samples analyzed in the present study (Table 1) (Elkins et al., 2016) have recently provided support for the presence of a distinct Jan Mayen mantle plume. Trace element and radiogenic isotope compositions of fresh samples identified a complex melting regime, in which Jan Mayen Island is likely underlain by a local mantle plume, and magma from that enriched source mixes radially with local mid-ocean ridge magmas along the adjacent SMR segment. The influence of the posited plume source on SMR magma supply, resulting ridge morphology, and geochemical composition of erupted basalts is significant and measurable.

Basalts from the NKR segment, on the other hand, do not clearly record the input of recycled, plume-derived magma (Elkins et al., 2016). Northern Kolbeinsey Ridge basalts, while enriched compared to the Middle Kolbeinsey Ridge, are distinct from Jan Mayen Island lavas and may be explained by an unusually high concentration of mafic material in the mantle source. Highly fusible mafic rocks may thus have produced the dramatically enhanced magma supply observed on the NKR, locally expressed as the Eggvin Bank bathymetric high and seamount.

Even with these recent findings, it was not possible to definitively rule out alternate models for local magma generation. Uranium-series analyses of MORB from elsewhere on the Kolbeinsey and Mohns Ridges have previously contributed better constraints on ambient regional mantle melting (Elkins et al., 2011; 2014), but high resolution sampling for the Jan Mayen area was lacking. One young, unaltered basalt sample from the NKR and a suite of Mohns Ridge MORB showed low, age-constrained $\left({ }^{231} \mathrm{~Pa} /{ }^{235} \mathrm{U}\right)$ activity ratios which require 
generation by rapid melting, best explained by a mafic lithology like eclogite in the melt source (Elkins et al., 2011; 2014). However, due to their low sampling density, those previous studies failed to clearly map the influence of mafic source rocks on NKR, SMR, or Jan Mayen Island volcanism.

\section{SAMPLING AND ${ }^{238} \mathrm{U}_{-}{ }^{234} \mathrm{U}-{ }^{230} \mathrm{Th}_{-}-{ }^{226} \mathrm{Ra}^{-{ }^{210}} \mathrm{Po}$ ANALYTICAL METHODS}

\subsection{Sampling and sample preparation}

Samples were collected from the submarine NKR by dredging during R/V Poseidon cruise 436 in 2012, and from the SMR with both dredge and remotely operated vehicle (ROV) during R/V Håkon Mosby cruise leg SM01 in 2001, at which time offshore Jan Mayen Island was also sampled (Table 1). Multibeam bathymetric mapping during the cruises allowed us to target the freshest volcanic rocks for sampling. All samples were previously analyzed for a full suite of major elements, trace elements, and long-lived radiogenic isotopes (Elkins et al., 2016). The subset analyzed here for U-series isotopes was selected based on sample quantity, volcanic glass abundance, and freshness. Three additional subaerial lavas from Jan Mayen Island previously described by Maaløe et al. (1986) were also measured here.

For all analyses except ${ }^{210} \mathrm{~Pb}$ (see below), those submarine samples were hand-picked to avoid visible alteration, palagonite, surface coatings, and phenocrysts. Two submarine historic flows from Jan Mayen Island (SM01-DR-5-5 and SM01-DR-60-43) lacked pure glass rinds and were instead hand-picked for visibly unaltered, glassy groundmass without phenocrysts. Handpicked samples were treated with a $0.1 \%$ oxalic acid $+2 \% \mathrm{H}_{2} \mathrm{O}_{2}$ leach for 15 minutes in an ultrasonic bath, followed by three rinses in ultrapure water, and then treated for an additional 15 minute leach in an ultrasonic bath with a $0.1 \% \mathrm{HCl}+2 \% \mathrm{H}_{2} \mathrm{O}_{2}$ solution and again rinsed three 
times. Following this light washing/leach to remove dust and $\mathrm{MnO}$ surface precipitates, samples were re-picked for glass purity and freshness.

Subaerial alkali basalt samples from Beerenberg Volcano on Jan Mayen Island have been described in greater detail in Maaløe et al. (1986). Although the precise sampling sites are not known, the two most primitive (highest $\mathrm{MgO}$ content) samples and one more evolved (lower MgO) sample available from the Maaløe et al. (1986) suite were selected for whole rock analysis for comparison with our submarine samples. Weathered exterior material was removed by sawing and the remainder prepared by hand-crushing and grinding to small rocks chips using an agate mortar and pestle. Aliquots of the resulting chips were ground to a fine powder using a zirconia shatterbox vessel and puck, and either the uncrushed chips or the fine powder were analyzed, as detailed below. To assess the possibility of zirconia contamination of U-series isotopes, a set of replicate analyses was conducted on both powder and rock chip aliquots for one sample (JM-84). While U and Th concentration results for JM-84 replicates are not identical, $\left({ }^{230} \mathrm{Th} /{ }^{232} \mathrm{Th}\right),\left({ }^{230} \mathrm{Th} /{ }^{238} \mathrm{U}\right)$, and $\left({ }^{226} \mathrm{Ra} /{ }^{230} \mathrm{Th}\right)$ measurements for the two dissolutions are replicated within uncertainty, suggesting sample heterogeneity caused slightly different $U$ and Th concentrations; we thus consider the U-series compositions of rock powders ground using a zirconia vessel to be unaffected by laboratory contamination for the elements and isotopes measured in this study.

All samples were subsequently dissolved using a $\mathrm{HF}-\mathrm{HNO}_{3}-\mathrm{HClO}_{4}$ procedure at either Bryn Mawr College or the University of Wyoming High Precision Isotope Laboratory. Uraniumseries isotopes were then separated and analyzed at the University of Wyoming using the ThermoFisher NEPTUNEPlus multi-collector inductively-coupled plasma mass spectrometer (MC-ICP-MS). Wherever samples were spiked for analysis by isotope dilution methods (see 
below), spikes were added to the samples by precise weighing. Samples and spikes were then heated for at least $48 \mathrm{hrs}$. with added $\mathrm{HClO}_{4}$ and fumed to dryness repeatedly to ensure full equilibration. Following ion exchange resin procedures to separate the elements of interest (see below), samples were dried, then dissolved in a dilute $\mathrm{HNO}_{3}$ solution for analysis.

\section{2. $\mathrm{U}$ and Th concentrations, ${ }^{230} \mathrm{Th} /{ }^{232} \mathrm{Th}$, and calculated ${ }^{230} \mathrm{Th} /{ }^{238} \mathrm{U}$}

$\mathrm{U}$ and Th were separated from an aliquot of dissolved sample using anion exchange resin. Uranium and Th concentrations were measured in a single dissolution aliquot by isotope dilution using ${ }^{233} \mathrm{U}$ and ${ }^{229} \mathrm{Th}$ spikes, respectively, following methods of Sims et al. (2008a; 2008b). Using isotopic abundances from $\mathrm{U}$ and Th concentrations, we calculate ${ }^{238} \mathrm{U} /{ }^{232} \mathrm{Th}$ ratios (Table 2). A separate aliquot of the same dissolution was used for analysis of $U$ and Th isotopic compositions and Ra concentrations by isotope dilution (see below). Uranium and Th were again separated from dissolved sample material using anion exchange resin prior to analysis, after Sims et al. (2002; 2008a; 2008b), Goldstein et al. (1989), and the summary in Elkins et al. (2011;

2014). Analysis of ${ }^{230} \mathrm{Th} /{ }^{232} \mathrm{Th}$ ratios in the second aliquot was conducted by MC-ICP-MS using the NEPTUNEPlus at the University of Wyoming. Uncertainties based on internal reproducibility are reported in Table 2 and are on the order of $0.1 \%$ for $\left({ }^{230} \mathrm{Th} /{ }^{232} \mathrm{Th}\right)$ activity ratios $(2 \sigma)$, while propagated uncertainties for mass tail corrections and external reproducibility are on the order of 0.5 to $1.0 \%$. Rock standards measured as unknowns are shown in Table 2 and produced good agreement with Th isotopes measured in previous interlaboratory studies (Sims et al., 2008a).

\section{3. ${ }^{234} \mathrm{U} /{ }^{238} \mathrm{U}$ ratios}


We measured ${ }^{234} \mathrm{U} /{ }^{238} \mathrm{U}$ ratios by $\mathrm{MC}-\mathrm{ICP}-\mathrm{MS}$ using the same dissolution aliquot as for Th and Ra isotopes, following separation with anion exchange resin, after Sims et al. (2008a; 2008b), Ball et al. (2008), and Elkins et al. (2011; 2014). We report uncertainties of 0.04-0.2\% $(2 \sigma)$ for internal reproducibility and $0.5 \%(2 \sigma)$ for rock standard accuracy, consistent with previous results (Richter et al., 2006; Sims et al., 2008a; 2008b). Standard analyses are presented in Table 2.

Seawater $\left({ }^{234} \mathrm{U} /{ }^{238} \mathrm{U}\right)$ activity ratios are known to be $1.146 \pm 0.005$ (Cheng et al., 2000; Henderson et al., 1993; Ku et al., 1977; Macdougall et al., 1979; Robinson et al., 2004; Thurber, 1962; Turekian and Bertine, 1971), so this ratio can serve as a sensitive indicator of chemical interaction between submarine basaltic rocks and seawater (Aumento, 1971; Bacon, 1978; Bourdon et al., 2000; Elkins et al., 2011; Macdougall, 1977; Macdougall et al., 1979; Sims and Hart, 2006; Sims et al., 2003; Störzer and Selo, 1976; 1978; Turekian and Bertine, 1971). The origin of this seawater signal is ${ }^{238} \mathrm{U}^{234} \mathrm{U}$ fractionation in continental rocks due to alpha recoil during weathering, such that weathered and variably leached subaerial rocks will develop $\left({ }^{234} \mathrm{U} /{ }^{238} \mathrm{U}\right)$ ratios other than unity (Porcelli and Swarzenski, 2003). We determine that a submarine sample is potentially altered by seawater interaction if it has $\left({ }^{234} \mathrm{U} /{ }^{238} \mathrm{U}\right)$ out of equilibrium, with an activity ratio different than $1.000 \pm 0.005$ (Table 2). We make an exception for sample POS436 253DR-E2 (with marginal $\left.\left({ }^{234} U /{ }^{238} U\right)=1.006\right)$ due to its young age and demonstrable similarity to POS436 253DR-6 $\left(\left({ }^{234} \mathrm{U} /{ }^{238} \mathrm{U}\right)=1.005\right)$, indicating that its geochemistry is relatively unaffected by minor seawater interaction.

\section{4. ${ }^{226} \mathrm{Ra} /{ }^{230} \mathrm{Th}$ ratios}


Radium abundances were determined by isotope dilution using $\mathrm{a}^{228} \mathrm{Ra}$ spike in the same sample dissolution aliquot used for measuring Th and $\mathrm{U}$ isotopic compositions above (Elkins et al., 2011; 2014; Sims et al., 1999; 2002; 2008a; 2008b; 2013b). Ra was subsequently purified by a series of columns: an anion exchange resin in $\mathrm{HNO}_{3}$, a cation exchange resin in $\mathrm{HCl}$, two passes through a Sr Spec resin in $\mathrm{HNO}_{3}$, and finally a series of an anion exchange column in $\mathrm{HNO}_{3}$ and a cation column in $\mathrm{HCl}$ immediately prior to mass spectrometry (Sims et al., 2008a; 2008b). The NEPTUNEPlus MC-ICP-MS at the University of Wyoming is equipped with a dual Retarding Potential Quadrupole (RPQ)/Secondary Electron Multiplier (SEM) collector block designed explicitly for measurements of ${ }^{226} \mathrm{Ra} /{ }^{228} \mathrm{Ra}$ ratios. An internal combined ${ }^{226} \mathrm{Ra}-{ }^{228} \mathrm{Ra}$ isotopic solution was characterized using a U010 solution of roughly equivalent count rates for isotopes of uranium $\left({ }^{234} \mathrm{U}\right.$ and $\left.{ }^{236} \mathrm{U}\right)$ and $\mathrm{Ra}$, and the characterized ${ }^{226} \mathrm{Ra}-{ }^{228} \mathrm{Ra}$ solution was subsequently used for sample-standard bracketing. The use of a multiple ion counting system alleviates errors associated with Faraday-SEM gain calibrations, and the sample-standard bracketing technique effectively accounts for any changes in plasma conditions or RPQ/SEM stability. Using this method, internal precision is entirely dependent on the count rates of the measured isotopes. More details on these analytical methods are presented in an additional publication (Scott et al., in prep.). As is typically the case for Ra isotopic analysis, despite good internal precision, error analysis remains controlled by the $1.2 \%$ uncertainty $(2 \sigma)$ in the known concentration for the NIST4967 ${ }^{226}$ Ra standard used to calibrate spike concentrations (Elkins et al., 2011; Sims et al., 2008b); our uncertainties are thus comparable to those from other laboratories (e.g., Elkins et al., 2011; Koornneef et al., 2010; Rubin et al., 2005; Sims et al., 1999; 2008b; 2013b). 


\section{5. ${ }^{210} \mathrm{~Pb} /{ }^{226} \mathrm{Ra}$ ratios}

Analyses of ${ }^{210}$ Po by alpha counting were performed at the University of Iowa, using methods described by Reagan et al. (2005; 2006), Sims et al. (2008b; 2013b), Waters et al. (2013a; 2013b), and Elkins et al. (2014). For the analyses, aliquots of $3 \mathrm{~g}$ of glass from two samples (POS436 253DR-6 and POS436 253DR-E2) were ground to small, glassy chips and leached as above. Samples were then spiked with a ${ }^{209}$ Po solution calibrated against the TML standard and monitored with repeat analysis of RGM-2. The samples were subsequently digested using an $\mathrm{HF}-\mathrm{HNO}_{3}$ method, dried, dissolved in $1 \mathrm{~N} \mathrm{HCl}$, and the solution passed over anion exchange resin to separate Po. The separated $\mathrm{Po}$ was autoplated on $\mathrm{Ag}$ in $\mathrm{HCl}$ and counted using an EGG Ortec alpha spectrometer.

\section{RESULTS}

\section{1. ${ }^{238} \mathrm{U}-{ }^{234} \mathrm{U}$ disequilibria}

Uranium isotopes were measured in samples analyzed for U-series isotope disequilibrium. One subaerial sample (JM-192) has a $\left({ }^{234} \mathrm{U} /{ }^{238} \mathrm{U}\right)$ activity ratio greater than unity, indicating disequilibrium resulting from weathering (Table 2). It is not considered further.

\section{2. ${ }^{238} \mathrm{U}-{ }^{230} \mathrm{Th}-{ }^{226} \mathrm{Ra}^{210} \mathrm{~Pb}$ disequilibria}

\subsubsection{Jan Mayen Island}

Uranium series measurements demonstrate that all unaltered samples have $\left({ }^{230} \mathrm{Th} /{ }^{238} \mathrm{U}\right)$ activity ratios greater than one, indicating disequilibrium with ${ }^{230} \mathrm{Th}$ excesses relative to ${ }^{238} \mathrm{U}$. The range of disequilibrium extends from 8-9\% (JM-84) to 15\% (JM-71, SM01-DR-5-5, and SM01-DR-60-43). The higher $\left({ }^{230} \mathrm{Th} /{ }^{238} \mathrm{U}\right)$ group includes both of the historically dated flows 
with lower $\mathrm{MgO}$ content $(\mathrm{MgO}=5.05$ to 6.45 wt. \%), as well as one undated, subaerial eruption $\left(\mathrm{MgO}=10.61\right.$ wt. \%; Elkins et al., 2016). $\left({ }^{226} \mathrm{Ra} /{ }^{230} \mathrm{Th}\right)$ activity ratios for Jan Mayen Island are within uncertainty of secular equilibrium for all subaerial flows and an undated submarine flow (SM01-DR-24-14), and range from 1.05 to 1.16 for the historical submarine samples (Fig. 2, Table 2).

\subsubsection{Southern Mohns Ridge}

Most SMR samples are relatively altered and/or lack the basaltic glass quantities necessary for U-series analysis. Only one sample, SM01-DR-67-4, could be successfully analyzed (Table 1, Fig. 1). Its $\left({ }^{230} \mathrm{Th} /{ }^{238} \mathrm{U}\right)$ activity ratio is within uncertainty of one, indicating secular equilibrium. Its $\left({ }^{226} \mathrm{Ra} /{ }^{230} \mathrm{Th}\right)$ ratio is also within uncertainty of equilibrium (Fig. 2, Table 2).

\subsubsection{Northern Kolbeinsey Ridge}

Uranium series results for the NKR are broadly similar to published results for other parts of the Kolbeinsey Ridge and a single formerly published, unaltered NKR basalt sample (Elkins et al., 2011). Northern Kolbeinsey Ridge basalts are characterized by consistently high $\left({ }^{230} \mathrm{Th} /{ }^{238} \mathrm{U}\right)=1.18$ to 1.36 . Of those, five unaltered samples $\left(\left({ }^{230} \mathrm{Th} /{ }^{238} \mathrm{U}\right)=1.23\right.$ to 1.32$)$ have $\left({ }^{226} \mathrm{Ra} /{ }^{230} \mathrm{Th}\right)$ out of equilibrium, with $\left({ }^{226} \mathrm{Ra} /{ }^{230} \mathrm{Th}\right)$ from 1.07 to 1.28 . The popping rock samples dredged from the Eggvin Bank seamount summit crater, POS436 253DR-E2 and POS436 253DR-6, have $\left({ }^{210} \mathrm{~Pb} /{ }^{226} \mathrm{Ra}\right)$ disequilibrium activity ratios equal to 1.14 and 1.06 , respectively, i.e., ${ }^{210} \mathrm{~Pb}$ excesses of $14 \%$ and $6 \%$ (Fig. 2, Table 2). 


\section{DISCUSSION}

\subsection{Age Constraints}

Interpretation of U-series isotopic compositions produced during melting and melt transport requires explicit constraints on sample ages to rule out isotopic decay since eruption. Two flows measured in this study have known historic eruption dates, SM01-DR-5-5 (September 1970) and SM01-DR-60-43 (January 1985), and their ${ }^{238} \mathrm{U}_{-}{ }^{230} \mathrm{Th}^{2}{ }^{226} \mathrm{Ra}$ disequilibria are thus considered primary and unaffected by decay. For all others, the presence of disequilibrium constrains the age of the sample to within five half-lives of the shorter-lived daughter isotope (e.g., ${ }^{226} \mathrm{Ra}$ has a half-life of 1600 yrs., so $\left({ }^{226} \mathrm{Ra} /{ }^{230} \mathrm{Th}\right)>1.0$ constrains sample eruption age to within the past 8000 yrs.). Sample SM01-DR67-4 is the only sample where all measured activities, including ${ }^{238} \mathrm{U}_{-}^{230} \mathrm{Th}$, are in secular equilibrium, placing no explicit constraints on its age but implying it is older than 375,000 years; the sample, and thus the SMR segment as a whole, therefore will not be evaluated further in this work. Where $\left({ }^{226} \mathrm{Ra} /{ }^{230} \mathrm{Th}\right)$ ratios are within uncertainty of secular equilibrium or were not measured, any detectable ${ }^{238} \mathrm{U}_{-}{ }^{230} \mathrm{Th}$ disequilibria must likewise be treated as minima due to potential aging since eruption (samples POS436 246DR-2, POS436 232DR-1, SM01-DR-24-14, JM-71, and JM-84; Table 2). The detection of $\left({ }^{210} \mathrm{~Pb} /{ }^{226} \mathrm{Ra}\right)$ disequilibrium in the Eggvin popping rocks constrains the sample age to younger than 100 years, which is sufficiently young for $\left({ }^{226} \mathrm{Ra} /{ }^{230} \mathrm{Th}\right)$ to remain effectively unchanged by decay since eruption. The $\left({ }^{226} \mathrm{Ra} /{ }^{230} \mathrm{Th}\right)$ activity ratios for all samples besides the popping rocks and the historic Jan Mayen lavas must therefore be treated as minima (Table 2). Age-constrained (not minimum) ${ }^{226} \mathrm{Ra} /{ }^{230} \mathrm{Th}$ ) ratios measured are thus 1.24 and 1.23 (samples POS 436 253DR-6 and POS 436 253DR-E2, respectively) for the NKR, and 1.05 (SM01-DR-60-43) and 1.16 (SM01-DR-5-5) for Jan Mayen Island (Table 2). A comparably high $\left({ }^{226} \mathrm{Ra} /{ }^{230} \mathrm{Th}\right)$ ratio of 1.28 
was measured in the unconstrained sample POS426 242DR-2b, which suggests that sample may also be relatively young and unaffected by radioactive decay since eruption.

\subsection{Interpretation of ${ }^{226} \mathrm{Ra}^{2}{ }^{210} \mathrm{~Pb}$ disequilibrium}

In contrast to the $\left({ }^{210} \mathrm{~Pb}\right)$ excesses in the two Eggvin popping rocks (Table 2), MORB from the Juan de Fuca Ridge and East Pacific Rise have small ${ }^{210} \mathrm{~Pb}$ deficits that have been interpreted to result from melting and are preserved by rapid migration from the source to the surface e.g., (Rubin et al., 2005; Sims et al., 2008b; Waters et al., 2013a). However, in other locations, volcanic rocks with ${ }^{210} \mathrm{~Pb}$ deficits have been interpreted to reflect ${ }^{222} \mathrm{Rn}$ loss resulting from persistent magma degassing (e.g., Condomines et al., 2003; Gauthier and Condomines, 1999; Rubin and Macdougall, 1989; Rubin et al., 1994; Sigmarsson, 1996; Sims et al., 2008b; 2013b; Turner et al., 2012). Excesses of ${ }^{210} \mathrm{~Pb}$ in basalts are most commonly interpreted to reflect gas and ${ }^{222} \mathrm{Rn}$ transfer from large volumes of magma into smaller volumes of magma (e.g., Berlo and Turner, 2010; Condomines et al., 2010; Gauthier and Condomines, 1999; Reagan et al., 2006; Reubi et al., 2015; Sims et al., 2008b; 2013b; Waters et al., 2013a).The Eggvin popping rocks contain overpressurized gas in their vesicles, consistent with the ${ }^{210} \mathrm{~Pb}$ excess resulting from gas accumulation. Although $\left({ }^{210} \mathrm{~Pb}\right)$ excess could also result from plagioclase accumulation in these phyric samples, as partition coefficients for $\mathrm{Pb}$ in plagioclase are higher than for $\mathrm{Ra}$ (Reagan et al, 2008a; Rubin et al., 2005; Sims et al., 2008b), we rule this out since our handpicking removed visible plagioclase. The low partition coefficients for $\mathrm{Pb}$ in basalts and basaltic andesites (Cooper et al., 2003; Cooper et al., 2016; Sims and DePaolo, 1997; Tepley et al., 2010) and modest $\left({ }^{210} \mathrm{~Pb} /{ }^{226} \mathrm{Ra}\right)$ values measured for plagioclase in basaltic andesites (Reagan et al., 2006) further suggest that this is a less likely explanation. 


\subsection{Magma generation and transport beneath Jan Mayen Island and the Eggvin Bank}

\subsection{1. ${ }^{238} U_{-}^{230}$ Th disequilibrium in Jan Mayen Island and NKR basalts}

Large $\left({ }^{230} \mathrm{Th}\right)$ excesses relative to $\left({ }^{238} \mathrm{U}\right)$ in volcanic rocks are typically used to infer that garnet was present in the residual solid during melting, because $\mathrm{U}$ is notably more compatible in garnet in the presence of melt than Th (e.g., Beattie, 1993; Elkins et al., 2008; Hauri et al., 1994; La Tourette et al., 1993; Pertermann and Hirschmann, 2003b; Pertermann et al., 2004; Salters and Longhi, 1999; Salters et al., 2002; Wood et al., 1999). The most likely garnet-bearing host rocks in the upper mantle are either garnet lherzolite or a more mafic lithology such as pyroxenite or eclogite (e.g., Allègre et al., 1984; Hirschmann and Stolper, 1996). While expected to be minor in the global upper mantle, eclogite and pyroxenite rocks have higher garnet modes than ultramafic rocks and represent particularly fertile melt sources (Hirschmann and Stolper, 1996; Sobolev et al., 2007), such that they may be important in producing high $\left({ }^{230} \mathrm{Th} /{ }^{238} \mathrm{U}\right)$ ratios in oceanic basalts. Consequently, garnet likely played an important role in mantle melt generation in Jan Mayen area lavas, as all age-constrained, unaltered samples show $\left({ }^{230} \mathrm{Th} /{ }^{238} \mathrm{U}\right)$ $>1$ (Table 2). It is not immediately clear from ${ }^{238} \mathrm{U}_{-}^{230} \mathrm{Th}$ disequilibria alone, however, what mantle lithology hosts that garnet.

Previous work suggests that the source type and melting mechanisms for the NKR may differ from Jan Mayen Island (Elkins et al., 2016), but such details are not clearly detectable using only ${ }^{238} \mathrm{U}_{-}{ }^{230} \mathrm{Th}$ disequilibria. Incorporation of ${ }^{230} \mathrm{Th}^{226} \mathrm{Ra}$ disequilibria into melting calculations and analysis is thus necessary for further interpretation.

\subsubsection{Model calculations for melt generation beneath the Eggvin Bank}


The ${ }^{230} \mathrm{Th}-{ }^{226} \mathrm{Ra}$ system records fractionations during melting and is particularly sensitive to variations in the melting rate, because of the relatively short half-life of ${ }^{226} \mathrm{Ra}$ (1600 yrs.). Coupled with ${ }^{238} \mathrm{U}_{-}{ }^{230} \mathrm{Th},{ }^{226} \mathrm{Ra}$ therefore presents a useful means of testing for lithologic variations and differences in upwelling rate (e.g., due to the presence of an actively-upwelling mantle plume). Mafic rocks are expected to melt considerably faster and with higher melt productivities than peridotites, due to a lower temperature solidus and narrower melting interval (Elkins et al., 2008; Hirschmann and Stolper, 1996; Kogiso et al., 2003; 2004; Pertermann and Hirschmann, 2003a). We observe that, like many other hotspot lavas (e.g., Azores (Bourdon et al., 2005; Prytulak et al., 2014), Hawaii (Sims et al., 1999), Samoa (Sims et al., 2008b), and Iceland (Koornneef et al., 2012)), age-constrained ${ }^{230} \mathrm{Th}-{ }^{226} \mathrm{Ra}$ disequilibria are relatively low (closer to secular equilibrium) for the Jan Mayen region, and are notably lower at Jan Mayen Island than for the NKR. If they record the primary melt generation process, these $\left({ }^{226} \mathrm{Ra} /{ }^{230} \mathrm{Th}\right)$ values nearer secular equilibrium could suggest relatively high melting rates, possibly due to the presence of a more fusible lithology like eclogite. In many model scenarios, $\left({ }^{226} \mathrm{Ra} /{ }^{230} \mathrm{Th}\right)$ is also particularly influenced by changes in the melt porosity of the source region (Sims et al., 1999; 2002; Spiegelman and Elliott, 1993). ${ }^{230} \mathrm{Th}-{ }^{226} \mathrm{Ra}$ disequilibria can additionally be affected by age decay during melt transport, age decay in crustal magma chambers, and magma chamber fractionation processes (e.g., Bourdon et al., 2005; Condomines et al., 2003; Cooper et al., 2001; 2003; Kokfelt et al., 2005; Koornneef et al., 2012; Prytulak et al., 2014; Reagan et al., 1992; Rubin et al., 2005; Saal and Van Orman, 2004; Sims et al., 1999; 2002; 2003; 2008b; 2013b).

To assess these possibilities, we employ a series of one-dimensional time-dependent melting models that consider a range of upwelling rates and lithologic source rocks. We use the UserCalc online calculator (Spiegelman, 2000) to determine reactive porous flow lava 
compositions after Spiegelman and Elliott (1993) for both a 2-layer (spinel- and garnet-bearing) peridotite source and a pure eclogite source; and a dynamic melting calculation after McKenzie (1985) and Zou and Zindler (2000) for garnet peridotite and eclogite sources, all with constant melt productivity (Table 3, Fig. 3). The peridotite composition considered is that of a fertile lherzolite, which permits us to better test the ability of a peridotite source to generate sufficiently high $\left.{ }^{230} \mathrm{Th} /{ }^{238} \mathrm{U}\right)$ ratios in the absence of a mafic lithology. The eclogite is similar in composition to the G2 experimental composition from Pertermann and Hirschmann (2003a). While the melting of either peridotitic or eclogitic rocks likely involves nonlinear variations in melt productivity with melt fraction (e.g., Elkins et al., 2011; Hirschmann and Stolper, 1996; Koornneef et al., 2012; Langmuir et al., 1992; Pertermann and Hirschmann, 2003a; Pertermann et al., 2004; Rudge et al. 2013; Sims et al., 2013a; Stracke et al., 2003b; 2006; Turner et al., 2015; Waters et al., 2011), the far simpler scenario of constant melt productivity is shown here to be sufficient for testing the impact of an eclogitic mantle source rock on basalt isotopic composition. Outcomes of our calculations are compared to a selected range of disequilibrium values for the Eggvin Bank $\left(\left({ }^{230} \mathrm{Th} /{ }^{238} \mathrm{U}\right)=1.23\right.$ to $1.36,\left({ }^{226} \mathrm{Ra} /{ }^{230} \mathrm{Th}\right)=1.24$ to 1.28$\left.)\right)$ and Jan Mayen Island $\left(\left({ }^{230} \mathrm{Th} /{ }^{238} \mathrm{U}\right)=1.15,\left({ }^{226} \mathrm{Ra} /{ }^{230} \mathrm{Th}\right)=1.05\right.$ to 1.16$)$ (Fig. 3). We only consider ageconstrained values for the minima in these ranges, while samples unconstrained with respect to age were permitted for establishing the upper bounds.

\subsubsection{Peridotite mantle melting calculations for the Eggvin Bank.}

Broadly, our results for reactive porous flow melting calculations (Fig. 3) show that NKR MORB compositions are poorly explained by melting of a peridotitic source. The melting rates and maximum residual porosities tested overall generate lower $\left({ }^{230} \mathrm{Th} /{ }^{238} \mathrm{U}\right)$ and higher 
$\left({ }^{226} \mathrm{Ra} /{ }^{230} \mathrm{Th}\right)$ than those observed for the NKR and Eggvin Bank. In two-layer, reactive porous flow peridotitic melting scenarios, the high $\left({ }^{230} \mathrm{Th} /{ }^{238} \mathrm{U}\right)$ ratios generated in the garnet peridotite stability field are poorly preserved after prolonged, subsequent melt interaction with a garnetfree spinel peridotite in the shallower part of the column (Fig. 3). High- $\left({ }^{230} \mathrm{Th} /{ }^{238} \mathrm{U}\right.$ ) lavas can only erupt from peridotite melt regimes if shallow reactive porous flow is suppressed, for example by the efficient extraction from depth through high-porosity conduits (e.g., Iwamori, 1994; Jull et al., 2002; Kelemen et al., 1997; Lundstrom, 2000; Sims et al., 2002; Waters et al., 2011).

Models using the dynamic melting of a peridotitic source rather than reactive porous flow similarly indicate that such melts should have high $\left({ }^{226} \mathrm{Ra} /{ }^{230} \mathrm{Th}\right)$ at moderate $\left({ }^{230} \mathrm{Th} /{ }^{238} \mathrm{U}\right)$, features which we do not observe in our NKR samples (Fig. 3c). Although dynamic and reactive porous flow melting calculations do not typically incorporate the effects of aging during transport, some models have done so, particularly for $\left({ }^{226} \mathrm{Ra} /{ }^{230} \mathrm{Th}\right)$ (e.g., Sims et al., 2002; Stracke et al., 2006). Nonetheless, aging cannot explain the high $\left({ }^{230} \mathrm{Th} /{ }^{238} \mathrm{U}\right)$ that we observe. While it is unlikely that any area of upper mantle contains $100 \%$ mafic rocks (for instance, the major element compositions of eclogite melts are silicic, not basaltic; e.g., Sobolev et al., 2007)), and our model calculation uncertainties cannot rule out contributions of small quantities of melt derived from peridotite in a magma mixture, NKR magmas are not likely to have been produced from a dominantly peridotitic source.

\subsubsection{Eclogite mantle melting calculations for the Eggvin Bank.}

Predicted U-series compositions for magmas derived from a pure eclogite source are far closer to observed values, particularly for the high observed $\left({ }^{230} \mathrm{Th} /{ }^{238} \mathrm{U}\right)$ for the NKR, suggesting a 
significant melt contribution from mafic sources to the lavas. This is well supported by the major and trace element compositions observed for Eggvin Bank magmas, which are characterized by the high $\mathrm{Pb}$ and $\mathrm{SiO}_{2}$ and low $\mathrm{Al}_{2} \mathrm{O}_{3}$ and $\mathrm{FeO}$ contents expected for eclogite-derived melts (Elkins et al., 2016; Pertermann et al., 2004). However, as for peridotites, both reactive porous flow and dynamic melt calculations for eclogite melting again predict $\left({ }^{226} \mathrm{Ra} /{ }^{230} \mathrm{Th}\right)$ ratios that are too high to explain the full range of observed, age-constrained compositions (Fig. 3b, d). Three possible explanations for this discrepancy are: 1) model uncertainty resulting from poorly constrained mineral/melt partition coefficients for Ra; 2) Th-Ra fractionation by feldspar crystallization in a magma chamber (e.g., Bourdon et al., 2005; Condomines et al, 2003; Cooper et al., 2001; 2003; Kokfelt et al., 2005; Reagan et al., 1992; Saal and Van Orman, 2004; Sims et al., 1999; 2002; Widom et al., 1992); and 3) modest (up to several thousand years), variable aging of magma during transport or storage after melting and prior to eruption (e.g., Sims et al., 2002). Neither the first nor the second scenario can be entirely ruled out. Regarding the third, decay during a magma storage or transport interval of at least 2400 years would support an initial $\left({ }^{226} \mathrm{Ra} /{ }^{230} \mathrm{Th}\right)$ ratio of $\sim 1.8$ for the samples with the lowest measured ratios from Eggvin Bank, which corresponds to an approximate maximum residual porosity of $0.5 \%$ for the dynamic melting model. Measured $\left({ }^{230} \mathrm{Th} /{ }^{238} \mathrm{U}\right)$ ratios and initial $\left({ }^{226} \mathrm{Ra} /{ }^{230} \mathrm{Th}\right)=\sim 1.8$ corresponds to a constant mantle upwelling rate of $30 \mathrm{~m} / \mathrm{yr}$., given a $75 \mathrm{~km}$ melt column (i.e., $30 \mathrm{~m} / \mathrm{yr}$. x 2400 yrs. $=75 \mathrm{~km})$. A plausible scenario is thus for the magma to be produced by dynamic melting of an eclogite-rich mantle source, followed by the efficient extraction and rapid transport of the aggregated liquid via channelized flow, such as in a dunite channel (e.g., Kelemen et al., 1997). While the alternative of magma storage may be limited for a mid-ocean ridge overlying small or transient magma chambers, the Eggvin seamount could host a larger, more established chamber, 
although 2400 yrs. is a relatively long storage period, even at such slow spreading rates. Whatever the explanation for the mismatch between our high modeled and lower observed $\left.{ }^{226} \mathrm{Ra} /{ }^{230} \mathrm{Th}\right)$ values, the maximum residual porosity, which exerts the main variable control on ${ }^{230} \mathrm{Th}^{-226} \mathrm{Ra}$ disequilibrium in the primary melting process (e.g., Sims et al., 1999), remains poorly constrained for the NKR due to the large uncertainties and multiple possible crustal and transport effects on ${ }^{226}$ Ra activity.

Due to the longer half-life of ${ }^{230} \mathrm{Th}(75,600 \mathrm{yrs}$.$) , the \left({ }^{230} \mathrm{Th} /{ }^{238} \mathrm{U}\right)$ activity ratio of a magma showing ${ }^{230} \mathrm{Th}^{-226} \mathrm{Ra}$ disequilibrium will not be strongly affected by the age decay effects of magma transport or storage, so our model constraints on melting rate from Figs. $3 \mathrm{~b}$ and $3 \mathrm{~d}$ are considerably more robust. For a pure eclogite source, the dynamic melting rate predicted for NKR $\left({ }^{230} \mathrm{Th} /{ }^{238} \mathrm{U}\right)$ ratios is $\sim 5 \times 10^{-4} \mathrm{~kg} / \mathrm{m}^{3} / \mathrm{yr}$. (Fig. 3d). If eclogite melts very rapidly, perhaps even reaching $100 \%$ melting over $\sim 75 \mathrm{~km}$ of upwelling (e.g., Elkins et al., 2008; Hirschmann and Stolper, 1996; Pertermann and Hirschmann, 2003a; Pertermann et al., 2004), this modeled melting rate would correspond to a solid upwelling rate of approximately $1.2 \mathrm{~cm} / \mathrm{yr}$ for a pure eclogitic mantle with constant melt productivity. Using the formula for melting rate $\mathrm{M}=\mathrm{W} \rho_{\mathrm{s}}$ $\mathrm{F}_{\max } / \mathrm{d}$ (where $\mathrm{M}$ is constant melting rate, $\mathrm{W}$ is solid upwelling rate, $\rho_{\mathrm{s}}$ is the solid density, $\mathrm{F}_{\max }$ is the maximum degree of melting achieved, and $d$ is the length of the column), this solid upwelling rate is relatively close to the passive upwelling rate expected for the Kolbeinsey Ridge half-spreading rate of $\sim 0.9 \mathrm{~cm} / \mathrm{yr}$. (Mosar et al., 2002). Using a reactive porous flow model, the predicted solid upwelling rate that generates calculated $\left({ }^{230} \mathrm{Th} /{ }^{238} \mathrm{U}\right)$ results closest to NKR basalts is higher, between 7.5 and $16 \mathrm{~cm} / \mathrm{yr}$., indicating relatively poor agreement between the two models. However, we consider dynamic melting with rapid, disequilibrium channelized extraction more plausible for a magma dominantly generated from an eclogite-rich source, due to 
the possibility that an eclogite-derived melt that chemically equilibrates with a solid peridotite matrix during low-porosity reactive transport may freeze, producing a hybrid pyroxenite rock rather than an extractable liquid. Recent work by Weatherley and Katz (2012; 2016) suggests that melting of mafic mantle rocks in a heterogeneous source is likely to produce channels near the base of the melt regime, making such an extraction scenario plausible at the NKR. It is thus likely that Eggvin Bank magmas are generated by dynamic, decompression melting during passive upwelling of a locally eclogite-rich mantle.

Even relatively modest quantities of mafic rocks, e.g. entrained as veins in peridotitic mantle, will contribute an outsized proportion of magma to any mixture with peridotite-derived melts, due to the deeper solidi and higher melt productivities of mafic lithologies: a pyroxenite or eclogite rock will have already reached relatively high melt fractions by the time any coexisting peridotite has begun to melt (Elkins et al., 2008; 2011; 2014; Hirschmann and Stolper, 1996; Pertermann and Hirschmann, 2003a; Prytulak and Elliott, 2009; Sims et al., 2013a; Stracke et al., 1999; Turner et al., 2015; Waters et al., 2011). The exact details of the compositions of mafic and ultramafic lithologies are needed to meaningfully constrain their exact proportions in the source, but the observed $\left({ }^{230} \mathrm{Th} /{ }^{238} \mathrm{U}\right)$ of NKR basalts make a predominance of mafic rocks in the source mantle likely.

\subsubsection{Model calculations for melt generation beneath Jan Mayen Island}

Lavas from Jan Mayen Island have lower $\left({ }^{230} \mathrm{Th} /{ }^{238} \mathrm{U}\right)$ activity ratios than NKR basalts (closer to secular equilibrium) and thus are more readily explained by contributions from both eclogite and peridotite melts to a magma mixture. A wide range of melt compositions and mixtures are plausible, making it difficult to precisely constrain the proportions of magma likely 
contributed from peridotitic vs. mafic sources. In Figure 3c, dynamic melting of pure garnet peridotite would require melting rates of $1 \times 10^{-4}$ to $2 \times 10^{-4} \mathrm{~kg} / \mathrm{m}^{3} / \mathrm{yr}$. to explain $\left({ }^{230} \mathrm{Th} /{ }^{238} \mathrm{U}\right)$ ratios alone, which for a $20 \%$ melt over $\sim 100 \mathrm{~km}$ (reasonable for garnet peridotite melting) (e.g., Asimow et al., 2001) corresponds to solid upwelling rates of 1.5 to $3 \mathrm{~cm} / \mathrm{yr}$. This rate is considerably elevated compared to the nearby Kolbeinsey Ridge half-spreading rate of 0.9 $\mathrm{cm} / \mathrm{yr}$., which should approximate regional passive mantle upwelling beneath adjacent midocean ridges (Mosar et al., 2002). Reactive porous flow melting of a pure, two-layer peridotite source (Fig. 3a) predicts significantly lower $\left({ }^{230} \mathrm{Th} /{ }^{238} \mathrm{U}\right)$ ratios than observed in Jan Mayen magmas, but contributions from a reactive porous flow peridotite source to a binary mixture derived in part from melting mafic rocks cannot be ruled out (Fig. 3b).

However, dynamic melting of a pure eclogite mantle source (Fig. 3d) more closely approximates the compositions of Jan Mayen Island lavas than either dynamic or reactive porous flow melting of pure peridotite: while measured ${ }^{226} \mathrm{Ra}$ excesses are slightly lower than modeled outcomes, as for the Eggvin Bank, $\left({ }^{230} \mathrm{Th} /{ }^{238} \mathrm{U}\right)$ is readily explained by combined peridotitic and eclogitic melting. Likewise, for the NKR basalts, $\left({ }^{226} \mathrm{Ra} /{ }^{230} \mathrm{Th}\right)$ of Jan Mayen lavas can be readily explained by either feldspar fractionation or several thousand years of decay prior to eruption; and likewise, as a result only broad conclusions can be drawn from $\left({ }^{226} \mathrm{Ra} /{ }^{230} \mathrm{Th}\right)$ values alone.

While our model results do indicate the likely importance of a mafic mantle source component beneath both the Eggvin Bank and Jan Mayen Island, the likely contributing quantities of peridotite-derived magmas to a binary melt mixture are considerably higher for Jan Mayen Island, with its lower $\left({ }^{230} \mathrm{Th} /{ }^{238} \mathrm{U}\right)$. The addition of a substantial quantity of peridotitederived magma is less likely at the Eggvin Bank. This provides independent support for conclusions previously drawn from radiogenic isotope and trace element analyses on NKR 
samples, which also suggested a uniquely eclogite-dominated mantle source beneath the ridge (Elkins et al., 2016). Radiogenic isotope measurements further indicate that two distinct enriched mantle source compositions are necessary for the Eggvin Bank and Jan Mayen Island (Elkins et al., 2016) (Fig. 4). These findings complement former studies of Jan Mayen Island, which identified a mixture of mantle melt sources that are likely required to produce observed lava compositions (e.g., subcontinental lithospheric mantle, depleted upper mantle, an Iceland-like plume source, etc.; Debaille et al., 2009; Trønnes et al., 1999).

The predicted upwelling rates discussed above appear to support relatively slow mantle upwelling beneath the Eggvin Bank (suggesting minimal mantle plume influence) and more rapid upwelling beneath Jan Mayen Island, in agreement with previous suggestions of a local mantle plume there (Elkins et al., 2016; Schilling et al., 1999); uncertainties associated with melt modeling and the simplifying assumptions made above (e.g., constant melt productivity during dynamic melting scenarios), however, reduce confidence in the precise values of these predicted upwelling rates. Previous researchers have used a combination of experimental measurements and thermodynamic calculations to constrain variations in peridotite and eclogite melt productivity in a progressively melting mantle regime (e.g., Asimow et al., 2001; Hirschmann and Stolper, 1996; Pertermann and Hirschmann, 2003a; 2003b; Stolper and Asimow, 2007). That work determined that despite progressive depletion of the melt source, which drives the residue towards more refractory compositions during upwelling, melt productivity increases dramatically during adiabatic decompression. Variable melt productivity is thus expected to increase the aggregate liquid proportion derived from the shallow portion of the melt regime, compared to calculations that assume constant melt productivity. The increased contribution of spinel peridotite-derived melts would further decrease the ability of garnet peridotite 
geochemical signatures to persist through the entire melt regime. Variable productivities would thus make it even less likely that the high measured $\left({ }^{230} \mathrm{Th} /{ }^{238} \mathrm{U}\right)$ in Eggvin Bank and Jan Mayen Island basalts can be produced purely by peridotite melting. Thus while our modeling cannot definitively assign quantifiable upwelling rates to the underlying mantle in the study area, the measured results in this study strongly support a scenario where Jan Mayen mantle upwelling rates are qualitatively higher than those beneath the Eggvin Bank, even allowing for different lithologic makeups. The low observed $\left({ }^{226} \mathrm{Ra} /{ }^{230} \mathrm{Th}\right)$ ratios in both locations also allow for transport times that are significant relative to the ${ }^{226}$ Ra half-life (1600 yrs.), or for differentiation that fractionates Ra from Th.

\subsection{The global role of mantle eclogite in oceanic magmatism}

Past studies of hotspot and hotspot-ridge systems have variably interpreted ageconstrained ${ }^{238} \mathrm{U}_{-}^{230} \mathrm{Th}^{-226} \mathrm{Ra}$ disequilibria to indicate the presence of mantle eclogite or pyroxenite, the absence of mantle eclogite or pyroxenite, the influence of crustal contamination, no appreciable contamination, hydrous mantle, anhydrous mantle, and variable amounts of crustal storage, sometimes for the same ocean island locales (e.g., Bourdon et al., 1998; 2005; Claude-Ivanaj et al., 1998; 2001; Kokfelt et al., 2003; Koornneef et al., 2012; Phillips et al., 2016; Pietruszka et al., 2001; 2009; Prytulak and Elliott, 2009; Prytulak et al., 2014; Rubin et al., 2005; Sigmarsson et al., 1998; Sims et al., 1995; 1999; 2008b; 2013b; Turner et al., 1997). It appears that in many cases local circumstances are unique, making it difficult to draw broad global conclusions from U-series isotope research at hotspots. Even taking these limitations into account, however, we see that hotspot lavas overall globally show relatively low $\left({ }^{226} \mathrm{Ra} /{ }^{230} \mathrm{Th}\right)$ values across a wide range of $\left({ }^{230} \mathrm{Th} /{ }^{238} \mathrm{U}\right)$ values (Fig. 2b). As it appears unlikely that effects of 
magma transport times or plagioclase fractionation can be fully responsible for the low $\left({ }^{226} \mathrm{Ra} /{ }^{230} \mathrm{Th}\right)$ ratios observed globally at hotspots, we suggest that the observed widespread OIB pattern of low $\left({ }^{226} \mathrm{Ra} /{ }^{230} \mathrm{Th}\right)$ compared with global MORB is a general feature related in part to widespread contributions from rapidly melted, mafic source rocks at many hotspot settings. The global presence of eclogite and/or pyroxenite in the OIB source mantle also fits well with traceelement evidence for source components derived from subducted oceanic crust, and with recent, high-resolution seismic tomography showing robust, broad, likely thermochemical upwelling plumes from deep in the lower mantle (French and Romanowicz, 2015), which may entrain recycled mafic material.

\section{CONCLUSIONS}

The presence of highly fusible mafic source material entrained by a mantle plume beneath Jan Mayen Island is in good agreement with U-series disequilibrium measurements for many other hotspots, and confirms a basic mechanism for generating the variable $\left({ }^{230} \mathrm{Th} /{ }^{238} \mathrm{U}\right)$, overall low $\left({ }^{226} \mathrm{Ra} /{ }^{230} \mathrm{Th}\right)$, and weakly positive correlation between $\left({ }^{230} \mathrm{Th} /{ }^{238} \mathrm{U}\right)$ and $\left({ }^{226} \mathrm{Ra} /{ }^{230} \mathrm{Th}\right)$ observed for global oceanic hotspot lavas. ${ }^{226}$ Ra decay during transport and magma storage can further reduce $\left({ }^{226} \mathrm{Ra} /{ }^{230} \mathrm{Th}\right)$ and introduce variability at some ocean island settings.

The Eggvin Bank on the NKR, on the other hand, represents a unique ridge location, relatively unaffected by the adjacent Jan Mayen hotspot and likely mantle plume, but with numerous and consistent geochemical and isotopic indicators of a highly localized, eclogite-rich mantle source. A plausible source for mafic rocks in the northern Kolbeinsey mantle is delaminated, ancient, previously underplated subcratonic mafic material that has been locally entrained by mantle upwelling beneath the ridge axis. The geochemical makeup of Eggvin Bank 
basalts is distinct from Jan Mayen Island signatures, supporting a unique mantle composition and melt generation process beneath the Kolbeinsey Ridge. Uranium-series disequilibria represent a useful tool for identifying and interpreting the processes involved in crustal generation at midocean ridges, and permit differentiation between multiple scenarios for magma formation. At Jan Mayen, such methods distinguish between sources of mantle heterogeneity that derive from distinct origins and have important implications for the evolution of the regional North Atlantic upper mantle.

\section{Acknowledgments}

This work benefited from helpful and constructive feedback from V. Salters and an anonymous reviewer. Laboratory, sample preparation, and imaging assistance was provided by R. Davis, K. Meisenhelder, and R. Chernow, Jan Mayen Island samples from the Maaløe collection were provided by D. DePaolo, and I. Yeo and N. Augustin provided assistance with bathymetric maps from the R/V Poseidon expedition. We thank N. Augustin, M. Deutschmann, T. Laurila, K. Meisenhelder, M. Rothenbeck, F. van der Zwan, and I. Yeo for field assistance on the F.S. Poseidon expedition in 2012.

\section{Funding Sources}

This research was supported by the National Science Foundation [OCE-1061037/1060434 to L.J.E. and K.W.W.S].

\section{References}


Allègre, C.J., Hamelin, B., Dupré, B., 1984. Statistical analysis of isotopic ratios in MORB: the mantle blob cluster model and the convective regime of the mantle. Earth and Planetary Science Letters, 71: 71-84.

Asimow, P.D., Hirschmann, M.M., Stolper, E.M., 2001. Calculation of peridotite partial melting from thermodynamic models of minerals and melts. IV. Adiabatic decompression and the composition and mean properties of mid-ocean ridge basalts. Journal of Petrology, 42: 963-998.

Aumento, F., 1971. Uranium Content of Mid-Ocean Ridge Basalts. Earth and Planetary Science Letters, 11(2): 90-94.

Bacon, M.P., 1978. Radioactive Disequilibrium in Altered Mid-Oceanic Basalts. Earth and Planetary Science Letters, 39(2): 250-254.

Ball, L., Sims, K.W.W., Schwieters, J., 2008. Measurement of U-234/U-238 and Th-230/Th-232 in volcanic rocks using the Neptune MC-ICP-MS. Journal of Analytical Atomic Spectrometry, 23(2): 173-180.

Beattie, P., 1993. Uranium Thorium Disequilibria and Partitioning on Melting of Garnet Peridotite. Nature, 363(6424): 63-65.

Berlo, K., Turner, S., 2010. ${ }^{210} \mathrm{~Pb}-{ }^{226} \mathrm{Ra}$ disequilibria in volcanic rocks. Earth and Planetary Science Letters, 296(3-4): 155-164.

Blichert-Toft, J. et al., 2005. Geochemical segmentation of the Mid-Atlantic Ridge north of Iceland and ridge-hot spot interaction in the North Atlantic. Geochemistry Geophysics Geosystems, 6: 10.1029/2004GC000788.

Bourdon, B., Goldstein, S.J., Bourles, D., Murrell, M.T., Langmuir, C.H., 2000. Evidence from $10 \mathrm{Be}$ and $\mathrm{U}$ series disequilibria on the possible contamination of mid-ocean ridge basalt 
glasses by sedimentary material. Geochemistry Geophysics Geosystems, 1:

10.1029/2000GC000047.

Bourdon, B., Joron, J.L., Claude-Ivanaj, C., Allegre, C.J., 1998. U-Th-Pa-Ra systematics for the Grande Comore volcanics: melting processes in an upwelling plume. Earth and Planetary Science Letters, 164(1-2): 119-133.

Bourdon, B., Langmuir, C.H., Zindler, A., 1996. Ridge-hotspot interaction along the MidAtlantic Ridge between 37 degrees 30' and 40 degrees 30'N: The U-Th disequilibrium evidence. Earth and Planetary Science Letters, 142(1-2): 175-189.

Bourdon, B., Turner, S.P., Ribe, N.M., 2005. Partial melting and upwelling rates beneath the Azores from a U-series isotope perspective. Earth and Planetary Science Letters, 239: 4256.

Brandsdottir, B. et al., 2004. Tectonic details of the Tjornes fracture zone, an onshore-offshore ridge-transform in N-Iceland. Eos Trans. American Geophys. Union, 85(47, Suppl.): Abstract T41A-1172.

Breivik, A.J., Faleide, J.I., Mjelde, R., Flueh, E.R., 2009. Magma productivity and early seafloor spreading rate correlation on the northern Voring Margin, Norway - Constraints on mantle melting. Tectonophysics, 468(1-4): 206-223.

Breivik, A.J., Mjelde, R., Faleide, J.I., Murai, Y., 2006. Rates of continental breakup magmatism and seafloor spreading in the Norway Basin-Iceland plume interaction. Journal of Geophysical Research-Solid Earth, 111(B7). doi: 10.1016/J.Tecto.2008.09.020.

Chabaux, F., Allegre, C.J., 1994. U-238 Th-230-Ra-226 Disequilibria in Volcanics - a New Insight into Melting Conditions. Earth and Planetary Science Letters, 126(1-3): 61-74. 
Cheng, H. et al., 2000. The half-lives of uranium-234 and thorium-230. Chemical Geology, 169: $17-33$.

Claude-Ivanaj, C., Bourdon, B., Allegre, C.J., 1998. Ra-Th-Sr isotope systematics in Grande Comore Island: a case study of plume-lithosphere interaction. Earth and Planetary Science Letters, 164(1-2): 99-117.

Claude-Ivanaj, C., Joron, J.L., Allegre, C.J., 2001. U-238-Th-230-Ra-226 fractionation in historical lavas from the Azores: long-lived source heterogeneity vs. metasomatism fingerprints. Chemical Geology, 176(1-4): 295-310.

Cohen, A.S., O'Nions, R.K., 1993. Melting rates beneath Hawaii: Evidence from uranium series isotopes in recent lavas. Earth and Planetary Science Letters, 120: 169-175.

Condomines, M., Gauthier, P.-J., Sigmarsson, O., 2003. Timescales of Magma Chamber Processes and Dating of Young Volcanic Rocks. In: Bourdon, B., Henderson, G.M., Lundstrom, C.C., Turner, S.P. (Eds.), Uranium-Series Geochemistry. Reviews in Mineralogy and Geochemistry. Mineralogical Society of America, Washington, DC, pp. 125-174.

Condomines, M., Sigmarsson, O., Gauthier, P.J., 2010. A simple model of ${ }^{222} \mathrm{Rn}$ accumulation leading to ${ }^{210} \mathrm{~Pb}$ excesses in volcanic rocks. Earth and Planetary Science Letters, 293: 331-338.

Condomines, M., Tanguy, J.C., Michaud, V., 1995. Magma dynamics at Mt. Etna: Constraints from U-Th- $\mathrm{Ra}-\mathrm{Pb}$ radioactive disequilibria and $\mathrm{Sr}$ isotopes in historical lavas. Earth and Planetary Science Letters, 132: 25-41. 
Cooper, K.M., Goldstein, S.J., Sims, K.W.W., Murrell, M.T., 2003. Uranium-series chronology of Gorda Ridge volcanism: new evidence from the 1996 eruption. Earth and Planetary Science Letters, 206(3-4): 459-475.

Cooper, K.M., Reid, M.R., Murrell, M.T., Clague, D.A., 2001. Crystl and magma residence at Kilauea Volcano, Hawaii: ${ }^{230} \mathrm{Th}^{-226}$ Ra dating of the 1955 East Rift eruption. Earth and Planetary Science Letters, 184: 703-718.

Cooper, K.M., Sims, K.W.W., Eiler, J.M., Banerjee, N., 2016. Time scales of storage and recycling of crystal mush at Krafla Volcano, Iceland. Contributions to Mineralogy and Petrology, 171: 54. doi: 10.1007/s00410-016-1267-3.

Debaille, V. et al., 2009. Primitive off-rift basalts from Iceland and Jan Mayen: Os-isotopic evidence for a mantle source containing enriched subcontinental lithosphere. Geochimica Et Cosmochimica Acta, 73: 3423-3449.

Devey, C., 2012. RV Poseidon Cruise Report 436 [POS436]: North Kolbeinsey Ridge geochemistry and volcanology, 06.07.2012 (Kiel) - 31.07.2012 (Akureyri). GEOMAR, Kiel, Germany, 56 pp.

Donnelly, K.E., Goldstein, S.L., Langmuir, C.H., Spiegelman, M., 2004. Origin of enriched ocean ridge basalts and implications for mantle dynamics. Earth and Planetary Science Letters, 226(3-4): 347-366.

Elkins, L.J., 2015. Jan Mayen glass and whole rock chemistry. IEDA/Earthchem data set. doi: 10.1594/IEDA/100536.

Elkins, L.J., Gaetani, G.A., Sims, K.W.W., 2008. Partitioning of U and Th during garnet pyroxenite partial melting: Constraints on the source of alkaline ocean island basalts. Earth and Planetary Science Letters, 265(1-2): 270-286. 
Elkins, L.J. et al., 2016. North Atlantic plume-ridge interaction near Jan Mayen Island. Geochemical Perspectives Letters, 2: 55-67.

Elkins, L.J. et al., 2014. Melt generation beneath Arctic Ridges: Implications from U decay series disequilibria in the Mohns, Knipovich, and Gakkel Ridges. Geochimica Et Cosmochimica Acta, 127: 140-170.

Elkins, L.J. et al., 2011. Understanding melt generation beneath the slow spreading Kolbeinsey Ridge from ${ }^{238} \mathrm{U},{ }^{230} \mathrm{Th}$, and ${ }^{231} \mathrm{~Pa}$ excesses. Geochimica Et Cosmochimica Acta, 75(21): 6300-6329.

French, S.W., Romanowicz, B., 2015. Broad plumes rooted at the base of the Earth's mantle beneath major hotspots. Nature, 525: 95-99.

Gaina, C., Gernigon, L., Ball, P., 2009. Palaeocene-Recent plate boundaries in the NE Atlantic and the formation of the Jan Mayen microcontinent. Journal of the Geological Society, 166: 601-616.

Gauthier, P.J., Condomines, M., 1999. ${ }^{210} \mathrm{~Pb}-{ }^{226} \mathrm{Ra}$ radioactive disequilibria in recent lavas and radon degassing: Inferences on the magma chamber dynamics at Stromboli and Merapi volcanoes. Earth and Planetary Science Letters, 172: 111-126.

Glebovsky, V.Y. et al., 2006. Formation of the Eurasia Basin in the arctic ocean as inferred from geohistorical analysis of the anomalous magnetic. Geotectonics, 40(4): 263-281.

Goldstein, S.J., Murrell, M.T., Jackecky, D.R., 1989. Th and U isotopic systematics of basalts from the Juan de Fuca and Gorda Ridges by mass spectrometry. Earth and Planetary Science Letters, 96: 134-146. 
Goldstein, S.J., Murrell, M.T., Janecky, D.R., Delaney, J.R., Clague, D.A., 1991. Geochronology and Petrogenesis of Morb from the Juan-De-Fuca and Gorda Ridges by U-238 Th-230 Disequilibrium. Earth and Planetary Science Letters, 109(1-2): 255-272.

Goldstein, S.J., Murrell, M.T., Williams, R.W., 1993. Pa-231 and Th-230 Chronology of Midocean Ridge Basalts. Earth and Planetary Science Letters, 115(1-4): 151-159.

Haase, K.M., Devey, C.W., Mertz, D.F., Stoffers, P., GarbeSchonberg, D., 1996. Geochemistry of lavas from Mohns ridge, Norwegian-Greenland Sea: Implications for melting conditions and magma sources near Jan Mayen. Contributions to Mineralogy and Petrology, 123(3): 223-237.

Haase, K.M., Devey, C.W., Wieneke, M., 2003. Magmatic processes and mantle heterogeneity beneath the slow-spreading northern Kolbeinsey Ridge segment, North Atlantic. Contributions to Mineralogy and Petrology, 144(4): 428-448.

Hanan, B.B., Blichert-Toft, J., Kingsley, R., Schilling, J.G., 2000. Depleted Iceland mantle plume geochemical signature: artifact of multicomponent mixing? Geochemistry Geophysics Geosystems, 1(4). doi: 10.1029/1999GC000009.

Hauri, E.H., 1996. Major-element variability in the Hawaiian mantle plume. Nature, 382(6590): 415-419.

Hauri, E.H., Wagner, T.P., Grove, T.L., 1994. Experimental and Natural Partitioning of Th, U, $\mathrm{Pb}$ and Other Trace-Elements between Garnet, Clinopyroxene and Basaltic Melts. Chemical Geology, 117(1-4): 149-166.

Hawkesworth, C.J. et al., 2000. Time scales of crystal fractionation in magma chambers -Integrating physical, isotopic and geochemical perspectives. Journal of Petrology, 41: 991-1006. 
Henderson, G.M., Cohen, A.S., Onions, R.K., 1993. U-234/U-238 Ratios and Th-230 Ages for Hateruma Atoll Corals - Implications for Coral Diagenesis and Seawater U-234/U-238 Ratios. Earth and Planetary Science Letters, 115(1-4): 65-73.

Hirschmann, M.M., Kogiso, T., Baker, M.B., Stolper, E.M., 2003. Alkalic magmas generated by partial melting of garnet pyroxenite. Geology, 31(6): 481-484.

Hirschmann, M.M., Stolper, E.M., 1996. A possible role for garnet pyroxenite in the origin of the "garnet signature" in MORB. Contributions to Mineralogy and Petrology, 124(2): 185208.

Hoffmann, D.L. et al., 2007. Procedures for accurate U and Th isotope measurements by high precision MC-ICPMS. International Journal of Mass Spectrometry, 264(2-3): 97-109.

Hooft, E.E.E., Brandsdóttir, B., Mjelde, R., Shimamura, H., Murai, Y., 2006. Asymmetric plume-ridge interaction around Iceland: The Kolbeinsey Ridge Iceland Seismic Experiment. Geochemistry Geophysics Geosystems, 7: Q05015. doi: 10.1029/2005GC001123.

Imsland, P., 1986. The volcanic eruption on Jan Mayen, January 1985: Interaction between a volcanic island and a fracture zone. Journal of Volcanology and Geothermal Research, 28(1-2): 45-53.

IOC, IHO, BODC, 2003. Centenary Edition of the GEBCO Digital Atlas, published on CDROM on behalf of the Intergovernmental Oceanographic Commission and the International Hydrographic Organization as part of the General Bathymetric Chart of the Oceans. British Oceanographic Data Centre, Liverpool, UK. 
Ito, G., Mahoney, J.J., 2005a. Flow and melting of a heterogeneous mantle: 1. Method and importance to the geochemistry of ocean island and mid-ocean ridge basalts. Earth and Planetary Science Letters, 230(1-2): 29-46.

Ito, G., Mahoney, J.J., 2005b. Flow and melting of a heterogeneous mantle: 2. Implications for a chemically nonlayered mantle. Earth and Planetary Science Letters, 230(1-2): 47-63.

Iwamori, H., 1994. 238U-230Th-226Ra and 235U-231Pa disequilibria produced by mantle melting with porous and channel flows. Earth and Planetary Science Letters, 125: 1-16.

Jaffey, A.H., Flynn, K.F., Glendeni.Le, Bentley, W.C., Essling, A.M., 1971. Precision Measurement of Half-Lives and Specific Activities of U-235 and U-238. Physical Review C, 4(5): 1889-1906.

Johnson, G.L., Heezen, B.C., 1967. Arctic Mid-Oceanic Ridge. Nature, 215(5102): 724.

Jull, M., Kelemen, P., Sims, K., 2002. Consequences of diffuse and channelled porous melt migration on uranium series disequilibria. Geochimica Et Cosmochimica Acta, 66: 41334148.

Kandilarov, A., Mjelde, R., Okino, K., Murai, Y., 2008. Crustal structure of the ultra-slow spreading Knipovich Ridge, North Atlantic, along a presumed amagmatic portion of oceanic crustal formation. Marine Geophysical Researches, 29(2): 109-134.

Kelemen, P.B., Hirth, G., Shimizu, N., Spiegelman, M., Dick, H.J.B., 1997. A review of melt migration processes in the adiabatically upwelling mantle beneath oceanic spreading ridges. Philosophical Transactions of the Royal Society of London Series a-Mathematical Physical and Engineering Sciences, 355(1723): 283-318. 
Klingelhofer, F., Geli, L., White, R.S., 2000. Geophysical and geochemical constraints on crustal accretion at the very-slow spreading Mohns Ridge. Geophysical Research Letters, 27(10): 1547-1550.

Kodaira, S., Mjelde, R., Gunnarsson, K., Shiobara, H., Shimamura, H., 1997. Crustal structure of the Kolbeinsey Ridge, North Atlantic, obtained by use of ocean bottom seismographs. Journal of Geophysical Research-Solid Earth, 102(B2): 3131-3151.

Kogiso, T., Hirschmann, M.M., 2001. Experimental study of clinopyroxenite partial melting and the origin of ultra-calcic melt inclusions. Contributions to Mineralogy and Petrology, 142(3): 347-360.

Kogiso, T., Hirschmann, M.M., Frost, D.J., 2003. High-pressure partial melting of garnet pyroxenite: possible mafic lithologies in the source of ocean island basalts. Earth and Planetary Science Letters, 216(4): 603-617.

Kogiso, T., Hirschmann, M.M., Pertermann, M., 2004. High-pressure partial melting of mafic lithologies in the mantle. Journal of Petrology, 45(12): 2407-2422.

Kokfelt, T.F., Hoernle, K., Hauff, F., 2003. Upwelling and melting of the Iceland plume from radial variation of U-238-Th-230 disequilibria in postglacial volcanic rocks. Earth and Planetary Science Letters, 214(1-2): 167-186.

Kokfelt, T.F., Lundstrom, C., Hoernle, K., Hauff, F., Werner, R., 2005. Plume-ridge interaction studied at the Galapagos spreading center: Evidence from Ra-226-Th-230-U-238 and Pa231-U-235 isotopic disequilibria. Earth and Planetary Science Letters, 234(1-2): 165-187.

Koornneef, J.M., Stracke, A., Aciego, S., Reubi, O., Bourdon, B., 2010. A new method for UTh-Pa-Ra separation and accurate measurement of U-234-Th-230-(231)pa-Ra-226 disequilibria in volcanic rocks by MC-ICPMS. Chemical Geology, 277(1-2): 30-41. 
Koornneef, J.M., Stracke, A., Bourdon, B., Gronvold, K., 2012. The influence of source heterogeneity on the U-Th-Pa-Ra disequilibria in post-glacial tholeiites from Iceland. Geochimica Et Cosmochimica Acta, 87: 243-266.

Ku, T.L., Knauss, K.G., Mathieu, G.G., 1977. Uranium in Open Ocean - Concentration and Isotopic Composition. Deep-Sea Research, 24(11): 1005-1017.

La Tourette, T.Z., Kennedy, A.K., Wasserburg, G.J., 1993. Thorium-uranium fractionation by garnet: Evidence for a deep source and rapid rise of oceanic basalts. Science, 261: 729742.

Langmuir, C., Klein, E.M., Plank, T., 1992. Petrological systematics of mid-ocean ridge basalts: constraints on melt generation beneath ocean ridges, Mantle Flow and Melt Generation at Mid-Ocean Ridges. Geophys. Monograph, pp. 183-280.

Lassiter, J.C., Hauri, E.H., Reiners, P.W., Garcia, M.O., 2000. Generation of Hawaiian posterosional lavas by melting of a mixed lherzolite/pyroxenite source. Earth and Planetary Science Letters, 178(3-4): 269-284.

Le Roux, L.J., Glendenin, L.E., 1963. Half-life of ${ }^{232}$ Th. Proceedings of the National Meeting on Nuclear Energy, Pretoria, South Africa: 83-94.

Ljones, F. et al., 2004. Crustal transect from the North Atlantic Knipovich Ridge to the Svalbard margin west of hornsund. Tectonophysics, 378(1-2): 17-41.

Lundstrom, C., 2000. Models of U-series disequilibria generation in MORB: the effects of two scales of melt porosity. Physics of the Earth and Planetary Interiors, 121(3-4): 189-204.

Lundstrom, C.C., Gill, J., Williams, Q., Hanan, B.B., 1998. Investigating solid mantle upwelling beneath mid-ocean ridges using U-series disequilibria. II. A local study at 33 degrees Mid-Atlantic Ridge. Earth and Planetary Science Letters, 157(3-4): 167-181. 
Lundstrom, C.C., Gill, J., Williams, Q., Perfit, M.R., 1995. Mantle Melting and Basalt Extraction by Equilibrium Porous Flow. Science, 270(5244): 1958-1961.

Lundstrom, C.C., Sampson, D.E., Perfit, M.R., Gill, J., Williams, Q., 1999. Insights into midocean ridge basalt petrogenesis: U-series disequilibria from the Siqueiros Transform, Lamont Seamounts, and East Pacific Rise. Journal of Geophysical Research-Solid Earth, 104(B6): 13035-13048.

Maaløe, S., Sørensen, I.B., Hertogen, J., 1986. The trachybasaltic suite of Jan Mayen. Journal of Petrology, 27(2): 439-466.

Macdougall, J.D., 1977. Uranium in Marine Basalts - Concentration, Distribution and Implications. Earth and Planetary Science Letters, 35(1): 65-70.

Macdougall, J.D., Finkel, R.C., Carlson, J., Krishnaswami, S., 1979. Isotopic Evidence for Uranium Exchange during Low-Temperature Alteration of Oceanic Basalt. Earth and Planetary Science Letters, 42(1): 27-34.

Maclennan, J., Jull, M., McKenzie, D., Slater, L., Grönvold, K., 2002. The link between volcanism and deglaciation in Iceland. Geochem. Geophys. Geosyst., 3(11): 1-25.

Mckenzie, D., 1985. Th-230-U-238 Disequilibrium and the Melting Processes beneath Ridge Axes. Earth and Planetary Science Letters, 72(2-3): 149-157.

Mertz, D.F., Haase, K.M., 1997. The radiogenic isotope composition of the high-latitude North Atlantic mantle. Geology, 25(5): 411-414.

Mertz, D.F., Sharp, W.D., Haase, K.M., 2004. Volcanism on the Eggvin Bank (Central Norwegian-Greenland Sea, latitude similar to 71 degrees N): age, source, and relationship to the Iceland and putative Jan Mayen plumes. Journal of Geodynamics, 38(1): 57-83. 
Mjelde, R., Raum, T., Breivik, A.J., Faleide, J.I., 2008. Crustal transect across the North Atlantic. Marine Geophysical Researches, 29(2): 73-87.

Montesi, L.G.J., Behn, M.D., 2007. Mantle flow and melting underneath oblique and ultraslow mid-ocean ridges. Geophysical Research Letters 34: L24307. doi: $10.1029 / 2007 \mathrm{gl} 1031067$.

Mosar, J., Lewis, G., Torsvik, T.H., 2002. North Atlantic sea-floor spreading rates: implications for the Tertiary development of inversion structures of the Norwegian-Greenland Sea. Journal of the Geological Society, 159: 503-515.

Neumann, E.R., Schilling, J.G., 1984. Petrology of Basalts from the Mohns-Knipovich Ridge the Norwegian-Greenland Sea. Contributions to Mineralogy and Petrology, 85(3): 209223.

Niu, Y.L., Batiza, R., 1993. Chemical Variation Trends at Fast and Slow-Spreading Midocean Ridges. Journal of Geophysical Research-Solid Earth, 98(B5): 7887-7902.

Niu, Y.L., Batiza, R., 1997. Trace element evidence from seamounts for recycled oceanic crust in the eastern Pacific mantle. Earth and Planetary Science Letters, 148(3-4): 471-483.

Niu, Y.L., Bideau, D., Hekinian, R., Batiza, R., 2001. Mantle compositional control on the extent of mantle melting, crust production, gravity anomaly, ridge morphology, and ridge segmentation: a case study at the Mid-Atlantic Ridge 33-35 degrees N. Earth and Planetary Science Letters, 186(3-4): 383-399.

Okino, K. et al., 2002. Preliminary analysis of the Knipovich Ridge segmentation: influence of focused magmatism and ridge obliquity on an ultraslow spreading system. Earth and Planetary Science Letters, 202(2): 275-288. 
Peate, D.W., Hawkesworth, C.J., van Calsteren, P.W., Taylor, R.N., Murton, B.J., 2001. U-238Th-230 constraints on mantle upwelling and plume-ridge interaction along the Reykjanes Ridge. Earth and Planetary Science Letters, 187(3-4): 259-272.

Pedersen, R.B., Thorseth, I.H., Nygård, T.E., Lilley, M.D., Kelley, D.S., 2010. Hydrothermal activity at the Arctic mid-ocean ridges. In: Rona, P.A., Devey, C.W., Dyment, J., Murton, B.J. (Eds.), Diversity of Hydrothermal Systems on Slow Spreading Ocean Ridges. Geophysical Monograph Series. AGU, pp. 67-89.

Pertermann, M., Hirschmann, M., 2003a. Partial melting experiments on MORB-like pyroxenite between 2 and $3 \mathrm{GPa}$ : Constraints on the presence of pyroxenite in basalt source regions from solidus location and melting rate. Journal of Geophysical Research, 108. doi: 10.1029/2000JB000118.

Pertermann, M., Hirschmann, M.M., 2003b. Anhydrous partial melting experiments on MORBlike eclogite: Phase relations, phase compositions and mineral-melt partitioning of major elements at 2-3 GPa. Journal of Petrology, 44(12): 2173-2201.

Pertermann, M., Hirschmann, M.M., Hametner, K., Gunther, D., Schmidt, M.W., 2004. Experimental determination of trace element partitioning between garnet and silica-rich liquid during anhydrous partial melting of MORB-like eclogite. Geochemistry Geophysics Geosystems, 5: Q05A01. doi: 10.1029/2003gc000638.

Phillips, E.H., Sims, K.W.W., Sherrod, D.R., Salters, V.J.M, Blusztajn, J., Dulai, H., 2016. Isotopic constraints on the genesis and evolution of basanitic lavas at Haleakala, Island of Maui, Hawaii. Geochim. Cosmochim. Acta. doi: http://dx.doi.org/10.1016/j.gca.2016.08.017. 
Pietruszka, A.J., Hauri, E.H., Blichert-Toft, J., 2009. Crustal contamination of mantle-derived magmas within Piton de la Fournaise Volcano, Réunion Island. Journal of Petrology, 50(4): 661-684.

Pietruszka, A.J., Rubin, K.H., Garcia, M.O., 2001. Ra-226-Th-230-U-238 disequilibria of historical Kilauea lavas (1790-1982) and the dynamics of mantle melting within the Hawaiian plume. Earth and Planetary Science Letters, 186(1): 15-31.

Porcelli, D., Swarzenski, P.W., 2003. The behavior of U- and Th-series nuclides in groundwater. In: Bourdon, B., Henderson, G.M., Lundstrom, C.C., Turner, S.P. (Eds.), Uranium-Series Geochemistry. Reviews in Mineralogy and Geochemistry. Mineralogical Society of America, Washington, DC, pp. 317-361.

Prytulak, J. et al., 2014. Melting versus contamination effects on 238U-230Th-226Ra and 235U231Pa disequilibria in lavas from São Miguel, Azores. Chemical Geology, 381: 94-109.

Prytulak, J., Elliott, T., 2009. Determining melt productivity of mantle sources from U-238-Th230 and U-235-Pa-231 disequilibria; an example from Pico Island, Azores. Geochimica Et Cosmochimica Acta, 73(7): 2103-2122.

Reagan, M., Tepley, I., F.J., Gill, J.B., Wortel, M., Hartman, B., 2005. Rapid time scales of basalt to andesite differentiation at Anatahan volcano, Mariana Islands. Journal of Volcanology and Geothermal Research, 146: 171-183.

Reagan, M.K., Tepley, I., F.J., Gill, J.B., Wortel, M., Garrison, J., 2006. Timescales of degassing and crystallization implied by ${ }^{210} \mathrm{Po}-{ }^{210} \mathrm{~Pb}-{ }^{226} \mathrm{Ra}$ disequilibria for andesitic lavas erupted from Arenal volcano. Journal of Volcanology and Geothermal Research, 157: 135-146.

Reagan, M.K., Cooper, K.M., Pallister, J.S., Thornber, C.R., and Wortel, M., 2008a. Timing of degassing and plagioclase growth in lavas erupted from Mount St. Helens, 2004-2005, 
from ${ }^{210} \mathrm{Po}-{ }^{210} \mathrm{~Pb}-{ }^{226} \mathrm{Ra}$ disequilibria, in Sherrod, D.R., Scott, W.E., and Stauffer, P.H., A volcano rekindled: the first year of renewed eruption at Mount St. Helens, 2004-2006. U.S. Geological Survey Professional Paper 1750: 847-856.

Reagan, M.K., Turner, S., Legg, M., Sims, K.W.W., Hards, V.L., 2008b. ${ }^{238}$ U- and ${ }^{232}$ Th-decay series constraints on the timescales of crystal fractionation to produce the phonolite erupted in 2004 near Tristan da Cunha, South Atlantic Ocean. Geochimica Et Cosmochimica Acta, 72: 4367-4378.

Reagan, M.K., Volpe, A.M., Cashman, K.V., 1992. ${ }^{238} \mathrm{U}$ and ${ }^{232}$ Th-series chronology of phonolite fractionation at Mount Erebus, Antarctica. Geochimica Et Cosmochimica Acta, 56: 1401-1407.

Reubi, O., Sims, K.W.W., Varley, N., Reagan, M., Eikenberg, J., 2015. Timescales of degassing and conduit dynamics inferred from ${ }^{210} \mathrm{~Pb}^{226} \mathrm{Ra}$ disequilibria in Volcan de Colima 19982010 andesitic magmas. In: Caricchi, L., Blundy, J.D. (Eds.), Chemical, Physical and Temporal Evolution of Magmatic Systems. Geological Society, Special Publications, London. doi: 10.1144/SP422.5.

Richter, S. et al., 2006. REIMEP 18: Inter-Laboratory Comparison for the Measurement of Uranium Isotopic Radios in Nitric Acid Solution. 22529, European Commission.

Robinson, L.F., Henderson, G.M., Hall, L., Matthews, I., 2004. Climatic control of riverine and Seawater uranium-isotope ratios. Science, 305(5685): 851-854.

Rubin, K.H., Macdougall, J.D., 1989. Submarine magma degassing and explosive magmatism at Macdonald (Tamarii) seamount. Nature, 341: 50-52.

Rubin, K.H., Macdougall, J.D., Perfit, M.R., $1994 .{ }^{210} \mathrm{Po}-{ }^{210} \mathrm{~Pb}$ dating of recent volcanic eruptions on the sea floor. Nature, 368: 841-844. 
Rubin, K.H., van der Zander, I., Smith, M.C., Bergmanis, E.C., 2005. Minimum speed limit for ocean ridge magmatism from $\mathrm{Pb}-210-\mathrm{Ra}-226-\mathrm{Th}-230$ disequilibria. Nature, 437(7058): 534-538.

Rudge, J.F., Maclennan, J., Stracke, A., 2013. The geochemical consequences of mixing melts from a heterogeneous mantle. Geochimica et Cosmochimica Acta, 114: 112-143.

Russo, C.J., Rubin, K.H., Graham, D.W., 2009. Mantle melting and magma supply to the Southeast Indian Ridge: The roles of lithology and melting conditions from U-series disequilibria. Earth and Planetary Science Letters, 278(1-2): 55-66.

Saal, A.E., Van Orman, J.A., 2004. The Ra-226 enrichment in oceanic basalts: Evidence for melt-cumulate diffusive interaction processes within the oceanic lithosphere. Geochemistry Geophysics Geosystems, 5. doi: 10.1029/2003gc000620.

Salters, V.J.M., Longhi, J., 1999. Trace element partitioning during the initial stages of melting beneath mid-ocean ridges. Earth and Planetary Science Letters, 166(1-2): 15-30.

Salters, V.J.M., Longhi, J.E., Bizimis, M., 2002. Near mantle solidus trace element partitioning at pressures up to $3.4 \mathrm{GPa}$. Geochemistry Geophysics Geosystems, 3(7): 1038. doi: 10.1029/2001GC000148.

Schilling, J.G., Kingsley, R., Fontignie, D., Poreda, R., Xue, S., 1999. Dispersion of the Jan Mayen and Iceland mantle plumes in the Arctic: A He-Pb-Nd-Sr isotope tracer study of basalts from the Kolbeinsey, Mohns, and Knipovich Ridges. Journal of Geophysical Research-Solid Earth, 104(B5): 10543-10569.

Scott, S.R. et al., in prep. On the application of using high abundances sensitivity filters for the measurement of radium isotopes by ID-MC-ICPMS. International Journal of Mass Spectrometry. 
Shen, Y., Forsyth, D.W., 1995. Geochemical Constraints on Initial and Final Depths of Melting beneath Midocean Ridges. Journal of Geophysical Research-Solid Earth, 100(B2): 22112237.

Shipilov, E.V., 2008. Generations of spreading basins and stages of breakdown of Wegener's pangea in the geodynamic evolution of the Arctic Ocean. Geotectonics, 42(2): 105-124.

Shorttle, O., Maclennan, J., 2011. Compositional trends of Icelandic basalts: Implications for short-length scale lithological heterogeneity in mantle plumes. Geochem. Geophys. Geosyst., 12. doi: 10.1029/2011gc003748.

Sigmarsson, O., 1996. Short magma chamber residence time at an Icelandic volcano inferred from U-series disequilibria. Nature, 382: 440-442.

Sigmarsson, O., Carn, S., Carracedo, J.C., 1998. Systematics of U-series nuclides in primitive lavas from the 1730-36 eruption on Lanzarote, Canary Islands, and implications for the role of garnet pyroxenites during oceanic basalt formations. Earth and Planetary Science Letters, 162(1-4): 137-151.

Sims, K.W.W. et al., 2003. Aberrant youth: Chemical and isotopic constraints on the origin of off-axis lavas from the East Pacific Rise, 9 degrees-10 degrees N. Geochemistry Geophysics Geosystems, 4: 8621. doi: 10.1029/2002gc000443.

Sims, K.W.W., DePaolo, D., 1997. Inferences about mantle magma sources from incopatible element concentration ratios in oceanic basalts. Geochimica Et Cosmochimica Acta, 61: $765-784$.

Sims, K.W.W. et al., 1999. Porosity of the melting zone and variations in the solid mantle upwelling rate beneath Hawaii: Inferences from U-238-Th-230-Ra-226 and U-235-Pa231 disequilibria. Geochimica Et Cosmochimica Acta, 63(23-24): 4119-4138. 
Sims, K.W.W. et al., 1995. Mechanisms of Magma Generation beneath Hawaii and Midocean Ridges - Uranium/Thorium and Samarium/Neodymium Isotopic Evidence. Science, 267(5197): 508-512.

Sims, K.W.W. et al., 2008a. An inter-laboratory assessment of the thorium isotopic composition of synthetic and rock reference materials. Geostandards and Geoanalytical Research, 32(1): 65-91.

Sims, K.W.W. et al., 2002. Chemical and isotopic constraints on the generation and transport of magma beneath the East Pacific Rise. Geochimica Et Cosmochimica Acta, 66(19): 34813504.

Sims, K.W.W., Hart, S.R., 2006. Comparison of Th, Sr, Nd and Pb isotopes in oceanic basalts: Implications for mantle heterogeneity and magma genesis. Earth and Planetary Science Letters, 245(3-4): 743-761.

Sims, K.W.W. et al., 2008b. ${ }^{238} \mathrm{U}_{-}{ }^{230} \mathrm{Th}_{-}{ }^{226} \mathrm{Ra}^{-}{ }^{210} \mathrm{~Pb}_{-}{ }^{210} \mathrm{Po},{ }^{232} \mathrm{Th}^{-}{ }^{228} \mathrm{Ra}$, and ${ }^{235} \mathrm{U}_{-}{ }^{231} \mathrm{~Pa}$ constraints on the ages and petrogenesis of Vailulu'u and Malumalu Lavas, Samoa. Geochemistry Geophysics Geosystems, 9: Q04003. doi: 10.1029/2007gc001651.

Sims, K.W.W. et al., 2013a. Short length scale mantle heterogeneity beneath Iceland probed by glacial modulation of melting. Earth and Planetary Science Letters, 379: 146-157.

Sims, K.W.W., et al., 2013b. On the timescales of magma genesis, melt evolution, crystal growth rates and magma degassing in the Erebus volcano magmatic system using the ${ }^{238} \mathrm{U},{ }^{235} \mathrm{U}-$ and ${ }^{232}$ Th-decay series. Journal of Petrology, 54: 235-237.

Sobolev, A.V., 2000. Recycled oceanic crust observed in 'ghost plagioclase' within the source of Mauna Loa lavas. Nature, 404: 986-990. 
Sobolev, A.V. et al., 2007. The amount of recycled crust in sources of mantle-derived melts. Science, 316(5823): 412-417.

Spiegelman, M., 2000. UserCalc: a web-based uranium series calculator for magma migration problems. Geochemistry Geophysics Geosystems, 1(8): 1016.

Spiegelman, M., Elliott, T., 1993. Consequences of Melt Transport for Uranium Series Disequilibrium in Young Lavas. Earth and Planetary Science Letters, 118(1-4): 1-20.

Standish, J.J., Sims, K.W.W., 2010. Young off-axis volcanism along the ultraslow-spreading Southwest Indian Ridge. Nature Geoscience, 3: 286-292.

Stolper, E.M., Asimow, P.D., 2007. Insights into mantle melting from graphical analysis of onecomponent systems. Am Journal Sci, 307: 1051-1139.

Störzer, D., Selo, M., 1976. Uranium contents and fission track ages of some basalts from the FAMOUS area. Bulletin de la Societe Geologique de France, 18(4): 807-810.

Störzer, D., Selo, M., 1978. Chrono-thermometry by fission-track methods of basalts from Legs 51-52 and some aspects of the alteration of these rocks by sea water. Bulletin de la Societe Geologique de France, 20(5, supplement): 250-253.

Stracke, A., Bourdon, B., 2009. The importance of melt extraction for tracing mantle heterogeneities. Geochimica Et Cosmochimica Acta, 73: 218-238.

Stracke, A., Bourdon, B., McKenzie, D., 2006. Melt extraction in the Earth's mantle: Constraints from U-Th-Pa-Ra studies in oceanic basalts. Earth and Planetary Science Letters, 244(12): 97-112.

Stracke, A., Salters, V.J.M., Sims, K.W.W., 1999. Assessing the presence of garnet-pyroxenite in the mantle sources of basalts through combined hafnium-neodymium-thorium isotope systematics. Geochemistry Geophysics Geosystems, 1. doi: 10.1029/1999gc000013. 
Stracke, A. et al., 2003a. Theistareykir revisited. Geochemistry Geophysics Geosystems, 4: -.

Stracke, A., Zindler, A., Salters, V.J.M., McKenzie, D., Gronvold, K., 2003b. The dynamics of melting beneath Theistareykir, northern Iceland. Geochemistry Geophysics Geosystems, 4: 8513. doi: 10.1029/2002gc000347.

Sturm, M.E., Goldstein, S.J., Klein, E.M., Karson, J.A., Murrell, M.T., 2000. Uranium-series age constraints on lavas from the axial valley of the Mid-Atlantic Ridge, MARK area. Earth and Planetary Science Letters, 181(1-2): 61-70.

Tepley, F.J., III, Lundstrom, C.C., McDonough, W.F., Thompson, A., 2010. Trace element partitioning between high-An plagioclase and basaltic to basaltic andesite melt at 1 atmosphere pressure. Lithos, 118: 82-94.

Tepley, F.J., Lundstrom, C.C., Sims, K.W.W., Hekinian, R., 2004. U-series disequilibria in MORB from the Garrett Transform and implications for mantle melting. Earth and Planetary Science Letters, 223(1-2): 79-97.

Thomas, L.E., Hawkesworth, C.J., Van Calsteren, P., Turner, S.P., Rogers, N.W., 1999. Melt generation beneath ocean islands: a U-Th-Ra isotope study from Lanzarote in the Canary Islands. Geochimica Et Cosmochimica Acta, 63: 4081-4099.

Thurber, D., 1962. Anomalous ${ }^{234} \mathrm{U} /{ }^{238} \mathrm{U}$ in nature. Journal of Geophysical Research, 67(11): 4518-4520.

Thy, P., Lofgren, G.E., Imsland, P., 1991. Melting relations and the evolution of the Jan Mayen magma system. Journal of Petrology, 32: 303-332.

Trønnes, R.G., Planke, S., Sundvoll, B., Imsland, P., 1999. Recent volcanic rocks from Jan Mayen: Low-degree melt fractions of enriched northeast Atlantic mantle. Journal of Geophysical Research-Solid Earth, 104(B4): 7153-7168. 
Trønnes, R.G., Planke, S., Sundvoll, B., Imsland, P., 1999. Recent volcanic rocks from Jan Mayen: Low-degree melt fractions of enriched northeast Atlantic mantle. Journal of Geophysical Research-Solid Earth, 104(B4): 7153-7168.

Turekian, K.K., Bertine, K.K., 1971. Deposition of Molybdenum and Uranium Along Major Ocean Ridge Systems. Nature, 229: 250-251.

Turner, S., Hawkesworth, C., Rogers, N., King, P., 1997. U-Th isotope disequilibria and ocean island basalt generation in the Azores. Chemical Geology, 139(1-4): 145-164.

Turner, S., Reagan, M., Vigier, N., Bourdon, B., 2012. Origins of 210Pb-226Ra disequilibria in basalts: New insights from the 1978 Asal Rift eruption. Geochemistry Geophysics Geosystems, 13: Q07002. doi: 10.1029/2012GC004173.

Turner, S. et al., 2015. Mid-ocean ridge basalt generation along the slow-spreading, South MidAtlantic Ridge (5-11 $\mathrm{S})$ : Inferences from ${ }^{238} \mathrm{U}_{-}{ }^{230} \mathrm{Th}-{ }^{226} \mathrm{Ra}$ disequilibria. Geochimica Et Cosmochimica Acta, 169: 152-166.

Waters, C.L. et al., 2013a. Sill to surface: Linking young off-axis volcanism with subsurface melt at the overlapping spreading center at $9^{\circ} 03^{\prime} \mathrm{N}$ East Pacific Rise. Earth and Planetary Science Letters, 369-370: 59-70.

Waters, C.L., Sims, K.W.W., Perfit, M.R., Blichert-Toft, J., Blusztajn, J., 2011. Perspective on the genesis of E-MORB from chemical and isotopic heterogeneity at $9^{\circ}-10^{\circ} \mathrm{N}$ East Pacific Rise. Journal of Petrology, 52: 565-602.

Waters, C.L. et al., 2013b. Recent volcanic accretion at $9^{\circ} \mathrm{N}-10^{\circ} \mathrm{N}$ East Pacific Rise as resolved by combined geochemical and geological observations. Geochemistry Geophysics Geosystems, 14(8): 2547-2574. 
Weatherley, S.M., Katz, R.F., 2012. Melting and channelized magmatic flow in chemically heterogeneous, upwelling mantle. Geochem. Geophys. Geosyst., 13(1): Q0AC18.

Weatherley, S.M., Katz, R.F., 2016. Melt transport rates in heterogeneous mantle beneath midocean ridges. Geochimica Et Cosmochimica Acta, 172: 39-54.

Widom, E., Carlson, R.W., Gill, J.B., Schmincke, H.U., 1997. Th-Sr-Nd-Pb isotope and trace element evidence for the origin of the Sao Miguel, Azores, enriched mantle source. Chemical Geology, 140(1-2): 49-68.

Widom, E., Schmincke, H.U., Gill, J.B., 1992. Processes and timescales in the evolution of chemically zoned trachyte: Fogo A, Sao Miguel, Azores. Contributions to Mineralogy and Petrology, 111: 311-328.

Wood, B.J., Blundy, J.D., Robinson, J.A.C., 1999. The role of clinopyroxene in generating Useries disequilibrium during mantle melting. Geochimica Et Cosmochimica Acta, 63(10): 1613-1620.

Workman, R.K., Hauri, E., Hart, S.R., Wang, J., Blusztajn, J., 2006. Volatile and trace elements in basaltic glasses from Samoa: Implications for water distribution in the mantle. Earth and Planetary Science Letters, 241: 932-951.

Yeo, I.A., Devey, C., LeBas, T.P., Augustin, N., Steinführer, A., 2016. Segment-scale volcanic episodicity: Evidence from the North Kolbeinsey Ridge, Atlantic. Earth and Planetary Science Letters, 439: 81-87.

Zou, H.B., Zindler, A., 2000. Theoretical studies of U-238-Th-230-Ra-226 and U-235-Pa-231 disequilibria in young lavas produced by mantle melting. Geochimica Et Cosmochimica Acta, 64(10): 1809-1817. 


\section{Figure Captions}

Figure 1. a. Northern Kolbeinsey Ridge multibeam bathymetry map, after Yeo et al. (2016). Sample dredge station locations are shown. b. Map of Jan Mayen region field area, with major morphologic and tectonic features labeled. Jan Mayen Island and SMR sample locations are shown, and area of high-resolution bathymetry mapping of the NKR measured aboard the R/V Poseidon is indicated. (See digital pdf for full-color figure.)

Figure 2. a. Diagram of $\left({ }^{230} \mathrm{Th} /{ }^{232} \mathrm{Th}\right)$ vs. $\left({ }^{238} \mathrm{U} /{ }^{232} \mathrm{Th}\right)$ showing results from this study. Samples without independent age constraints are shown as smaller data points, including the sample from the SMR (Table 2). Two samples with $\left({ }^{234} \mathrm{U} /{ }^{238} \mathrm{U}\right) \neq 1.0$, indicating weathering or alteration (Table 2), are shown using transparent data symbols. Published global oceanic data are also shown, filtered to exclude samples without independent age-constraints, or without measured $\left({ }^{234} \mathrm{U} /{ }^{238} \mathrm{U}\right)=1$, after Elkins et al. (2011) (Bourdon et al., 1996; 1998; Claude-Ivanaj et al., 1998; Claude-Ivanaj et al., 2001; Elkins et al., 2011; 2014; Goldstein et al., 1989; Goldstein et al., 1991; Goldstein et al., 1993; Kokfelt et al., 2003; Kokfelt et al., 2005; Koornneef et al., 2012; Lundstrom et al., 1995; 1998; 1999; Peate et al., 2001; Pietruszka et al., 2001; 2009; Prytulak et al., 2014; Prytulak and Elliott, 2009; Rubin et al., 2005; Russo et al., 2009; Sigmarsson et al., 1998; Sims and Hart, 2006; Sims et al., 1995; 1999; 2002; 2008b; Standish and Sims, 2010; Stracke et al., 2003a; 2003b; Sturm et al., 2000; Tepley et al., 2004; Turner et al., 1997; 2015; Waters et al., 2011; 2013a; 2013b; Widom et al., 1997). b. Diagram of $\left({ }^{226} \mathrm{Ra} /{ }^{230} \mathrm{Th}\right) \mathrm{vs}$. $\left({ }^{230} \mathrm{Th} /{ }^{238} \mathrm{U}\right)$ showing results from this study; three samples with known age constraints with respect to ${ }^{230} \mathrm{Th}^{-26}{ }^{22} \mathrm{Ra}$ (see text) are shown with full size data symbols, while others are shown with smaller symbols. Published global oceanic data are also shown for comparison (Bourdon et 
al., 1998; 2000; 2005; Claude-Ivanaj et al., 1998; 2001; Cohen and O'Nions, 1993; Elkins et al., 2011; 2014; Kokfelt et al., 2003; 2005; Koornneef et al., 2012; Lundstrom et al., 1998; 1999; Peate et al., 2001; Phillips et al., 2016; Pietruszka et al., 2001; 2009; Prytulak and Elliott, 2009; Prytulak et al., 2014; Rubin et al., 2005; Russo et al., 2009; Sigmarsson et al., 1998; Sims et al., 1995; 1999; 2002; 2008b; Standish and Sims, 2010; Sturm et al., 2000; Tepley et al., 2004; Turner et al., 1997; 2015; Waters et al., 2011; 2013a; 2013b). Mid-ocean ridge basalt data have been filtered to remove published samples without measured $\left({ }^{234} U /{ }^{238} U\right)=1.0$. Analyses from ocean islands that include no ${ }^{234} \mathrm{U}$ measurements are included for completeness and data comparison, but are indicated with transparent symbols. Some literature samples from ocean islands and mid-ocean ridges lack independent age constraints for ${ }^{230} \mathrm{Th}-{ }^{226} \mathrm{Ra}$ disequilibria, but those for which ages are known to be young relative to the half-life of ${ }^{226} \mathrm{Ra}(1600 \mathrm{yrs}$.) are indicated with a purple symbol outline; MORB erupted outside the ridge axis are indicated with internal "x" symbols. Dashed lines show compositions in secular equilibrium, where the activity ratios for $\left({ }^{226} \mathrm{Ra} /{ }^{230} \mathrm{Th}\right)$ or $\left({ }^{230} \mathrm{Th} /{ }^{238} \mathrm{U}\right)$ are equal to 1 . (See digital pdf for full-color figure.)

Figure 3. Gridded results of melt modeling calculations (see text, Table 3), plotted on diagrams of $\left({ }^{226} \mathrm{Ra} /{ }^{230} \mathrm{Th}\right)$ vs. $\left({ }^{230} \mathrm{Th} /{ }^{238} \mathrm{U}\right)$ : a. reactive porous flow melting of a two-layer peridotite source; b. reactive porous flow melting of an eclogite source; c. dynamic melting of a garnet peridotite source; and d. dynamic melting of an eclogite source. The dark red arrow in panel (a) shows the path followed by radioactive decay over time. Calculated melt compositions are shown for ranges of melting rates (bold lines and labels; labeled in $\mathrm{kg} / \mathrm{m}^{3} / \mathrm{yr}$.) and maximum residual porosities (thin lines; labeled as $\phi$ in percent porosity). Target value ranges based on measured compositions of age-constrained lavas (see text) from Jan Mayen Island ("JM," small red boxes) 
and the Eggvin Bank on the NKR ("EB," wide purple boxes) are also shown. Dashed lines show compositions in secular equilibrium, where activity ratios for $\left({ }^{226} \mathrm{Ra} /{ }^{230} \mathrm{Th}\right)$ or $\left({ }^{230} \mathrm{Th} /{ }^{238} \mathrm{U}\right)$ are equal to 1. (See digital pdf for full-color figure.)

Figure 4. Results for a. $\varepsilon_{\mathrm{Nd}}$ vs. $\varepsilon_{\mathrm{Hf}}$ (after Elkins et al., 2011; 2016) and $\left({ }^{230} \mathrm{Th} /{ }^{238} \mathrm{U}\right)$ vs. $\varepsilon_{\mathrm{Hf}}($ Elkins et al., 2011; this study), including data from Jan Mayen Island (Elkins et al., 2016; this study) for comparison. Previous work on radiogenic isotope and trace element data for this region demonstrated a mixing relationship between a unique trace-element enriched source beneath the Eggvin Bank and ambient depleted Kolbeinsey-type mantle (blue mixing line with labeled tick marks, after Elkins et al., 2016). Similar results can be seen for other radiogenic isotope ratios, including a demonstrable quantitative difference between enriched Eggvin mantle and the mantle source beneath Jan Mayen Island (not shown; see Elkins et al., 2016 for further comparisons and detailed discussion). Our new results demonstrate overlap in $\left({ }^{230} \mathrm{Th} /{ }^{238} \mathrm{U}\right)$ values, as observed above (see Figs. 2-3). However, NKR and Eggvin Bank samples demonstrate higher average $\left({ }^{230} \mathrm{Th} /{ }^{238} \mathrm{U}\right)$ than either Jan Mayen Island or the neighboring Middle Kolbeinsey Ridge segment, which models suggest is best explained by a significant melt contribution from an eclogite-rich mantle (see Fig. 2). 


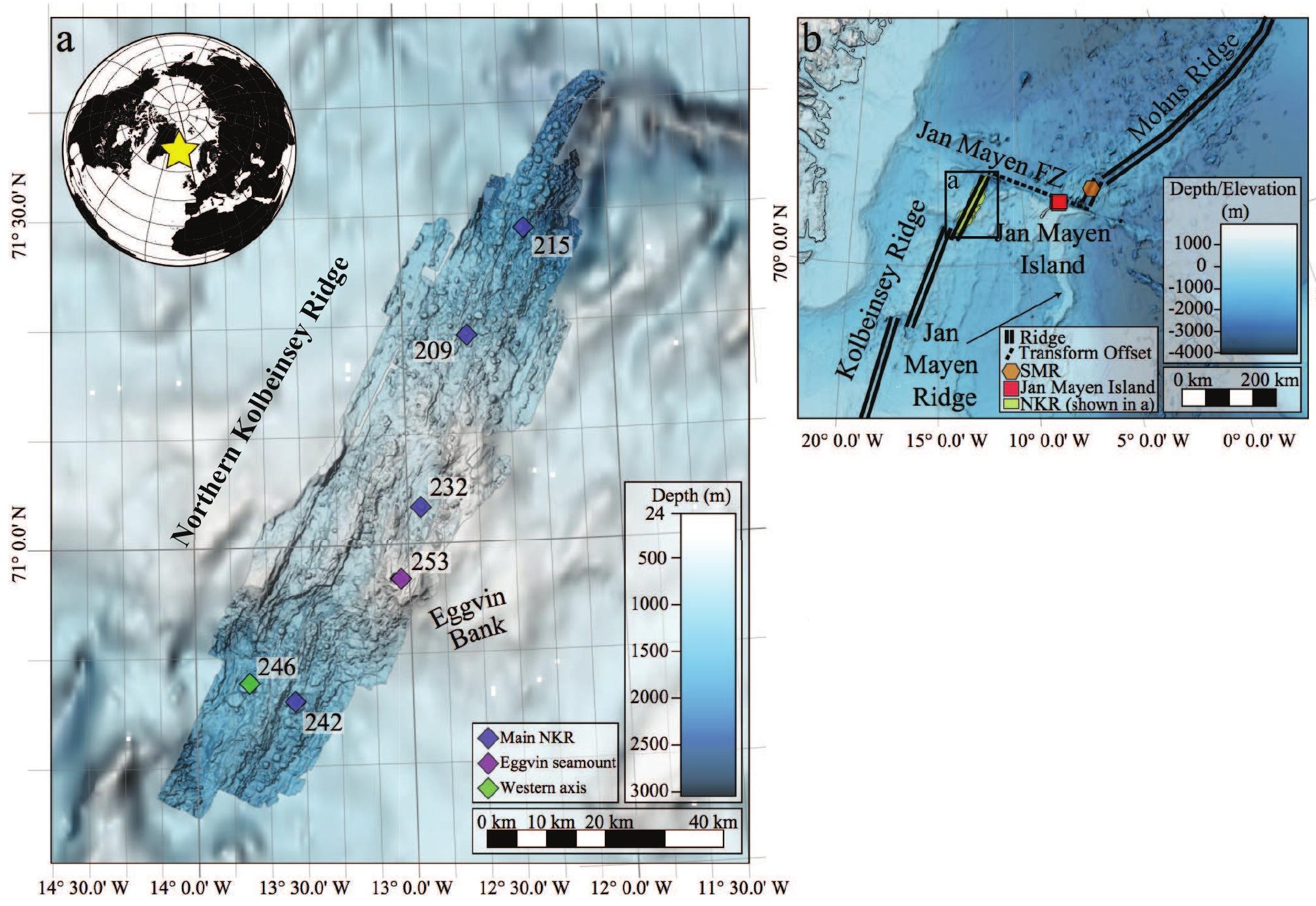

$5^{\circ} 0.0^{\prime} \mathrm{E}$ 

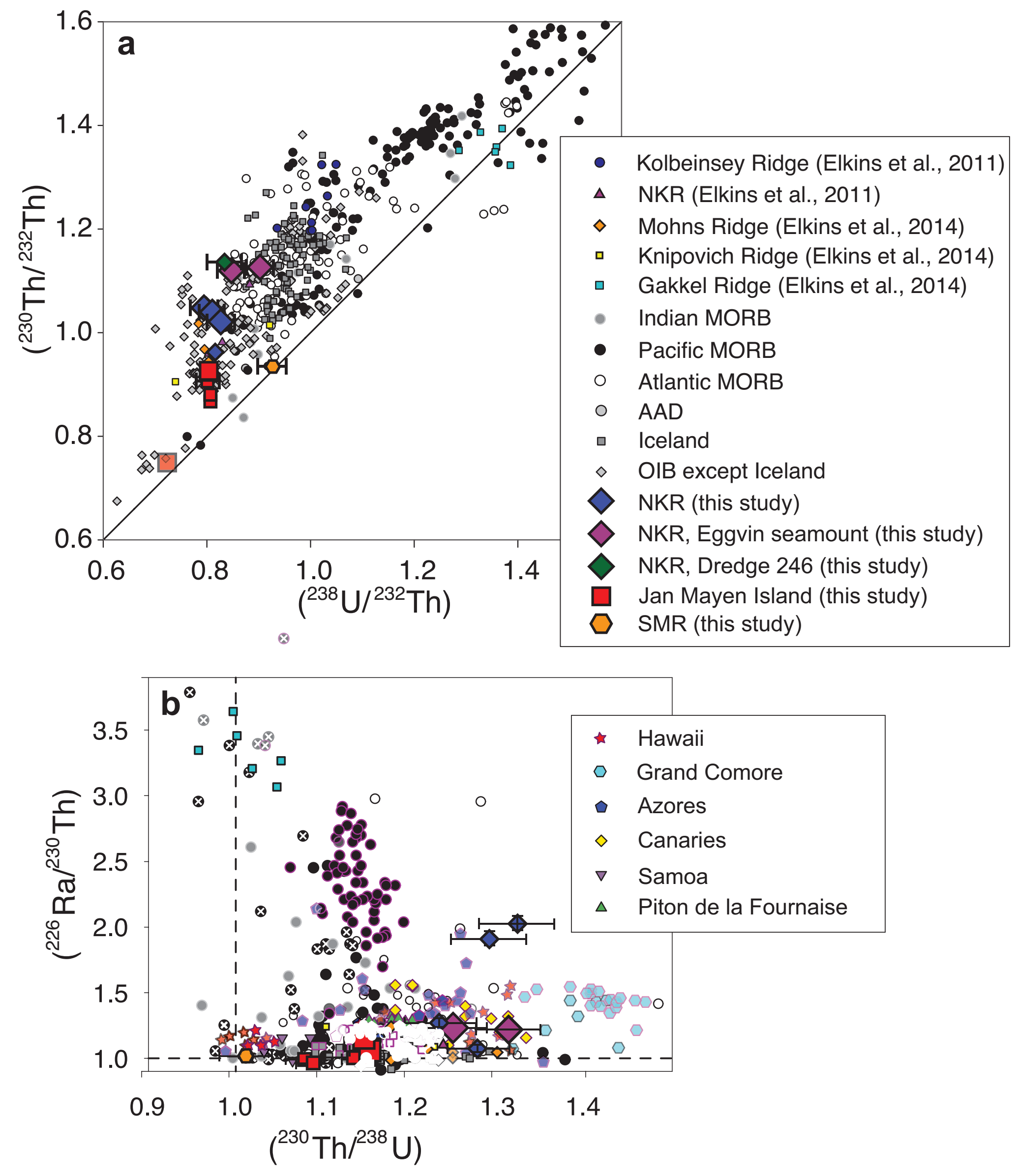
Table 1 Location information for submarine samples analyzed in this study.

\begin{tabular}{|c|c|c|c|c|c|c|c|c|c|}
\hline \multirow{2}{*}{ Sample number* } & \multirow{2}{*}{ Location } & \multirow{2}{*}{ Expedition $^{b}$} & \multirow{2}{*}{ Year } & \multicolumn{2}{|c|}{ Latitude $\left({ }^{\circ} \mathbf{N}\right)$} & \multicolumn{2}{|c|}{ Longitude $\left({ }^{\circ} \mathbf{W}\right)$} & \multicolumn{2}{|c|}{ Depth (m) } \\
\hline & & & & Start & Stop & Start & Stop & Start & Stop \\
\hline POS436 242DR-2b & NKR & R/V Poseidon Leg 436 & 2012 & 70.75997 & 70.76498 & 13.55035 & 13.54483 & 1559 & 1436 \\
\hline POS436 246DR-2 & NKR & R/V Poseidon Leg 436 & 2012 & 70.78942 & 70.79472 & 13.75350 & 13.75400 & 1714 & 1630 \\
\hline POS436 253DR-E2 & NKR & R/V Poseidon Leg 436 & 2012 & 70.94897 & 70.94742 & 13.03475 & 13.03770 & 207 & 175 \\
\hline POS436 253DR-6 & NKR & R/V Poseidon Leg 436 & 2012 & 70.94897 & 70.94742 & 13.03475 & 13.03770 & 207 & 175 \\
\hline POS436 232DR-1 & NKR & R/V Poseidon Leg 436 & 2012 & 71.05987 & 71.05655 & 12.95232 & 12.93983 & 622 & 578 \\
\hline POS436 209DR-2a & NKR & R/V Poseidon Leg 436 & 2012 & 71.31342 & 71.31592 & 12.70272 & 12.69447 & 1199 & 1205 \\
\hline POS436 215DR-1 & NKR & R/V Poseidon Leg 436 & 2012 & 71.47660 & 71.47597 & 12.39383 & 12.40617 & 1819 & 1703 \\
\hline SM01-DR-24-14 & JM & R/V Håkon Mosby, SM01 & 2001 & - & 71.1287 & - & 7.8082 & - & 738 \\
\hline SM01-DR-5-5 & $\mathrm{JM}$ & R/V Håkon Mosby, SM01 & 2001 & - & 71.1192 & - & 7.9187 & - & 47 \\
\hline SM01-DR-60-43 & $\mathrm{JM}$ & R/V Håkon Mosby, SM01 & 2001 & - & 71.1645 & - & 7.9880 & - & 222 \\
\hline SM01-DR67-4 & SMR & R/V Håkon Mosby, SM01 & 2001 & - & 71.2188 & - & 6.1713 & - & 806 \\
\hline
\end{tabular}

* All samples collected by dredge. For SM01 cruise, only end locations for dredges were recorded.

${ }^{a}$ SM01 sample depths are calculated from GEBCO global bathymetry (IOC, IHO, BODC, 2003).

${ }^{\mathrm{b}} \mathrm{R} / \mathrm{V}$ Poseidon sample information available in Earthchem/IEDA database (Elkins, 2015). 
Table 2. Uranium-series isotope measurements for samples from the Jan Mayen region. *

\begin{tabular}{|c|c|c|c|c|c|c|c|c|c|c|}
\hline & Location $* *$ & $\begin{array}{c}\text { Th } \\
(\mathbf{p p m})\end{array}$ & $\begin{array}{c}\mathbf{U} \\
(\mathbf{p p m})\end{array}$ & $\begin{array}{l}\left({ }^{230} \mathrm{Th}\right) / \\
\left({ }^{238} \mathrm{U}\right){ }^{\mathrm{c}}\end{array}$ & $\begin{array}{l}\left({ }^{238} \mathrm{U}\right) / \\
\left({ }^{232} \mathrm{Th}\right)\end{array}$ & $\begin{array}{l}\left({ }^{230} \mathrm{Th}\right) / \\
\left({ }^{232} \mathrm{Th}\right)\end{array}$ & $\begin{array}{c}\left({ }^{234} \mathrm{U}\right) / \\
\left({ }^{238} \mathrm{U}\right)\end{array}$ & $\begin{array}{c}\left({ }^{226} \mathrm{Ra}\right) / \\
\left({ }^{230} \mathrm{Th}\right)\end{array}$ & $\begin{array}{l}\left({ }^{210} \mathrm{Po}\right)^{\mathrm{b}} \\
(\mathrm{dpm} / \mathrm{g})\end{array}$ & $\begin{array}{r}\left({ }^{210} \mathrm{~Pb}\right) / \\
\left({ }^{226} \mathrm{Ra}\right)\end{array}$ \\
\hline \multicolumn{11}{|l|}{ Submarine samples: } \\
\hline POS436 242DR-2b & NKR & $0.85(1)$ & $0.231(7)$ & $1.23(4)$ & $0.83(3)$ & $1.0190(9)$ & $1.0038(8)$ & $1.28(4)$ & - & - \\
\hline POS436 246DR-2 & NKR & $0.232(4)$ & $0.064(2)$ & $1.36(6)$ & $0.83(3)$ & $1.136(2)$ & $1.002(2)$ & - & - & - \\
\hline POS436 253DR-E2 & NKR & $1.82(3)$ & $0.51(1)$ & $1.32(4)$ & $0.85(3)$ & $1.120(1)$ & $1.0060(6)$ & $1.23(4)$ & $0.65(2)$ & $1.14(6)$ \\
\hline POS436 253DR-6 & NKR & $1.74(4)$ & $0.52(1)$ & $1.25(4)$ & $0.90(3)$ & $1.124(1)$ & $1.0051(4)$ & $1.24(4)$ & $0.68(3)$ & $1.06(5)$ \\
\hline POS436 232DR-1 & NKR & $0.564(7)$ & $0.152(3)$ & $1.18(3)$ & $0.82(2)$ & $0.9598(8)$ & $1.0025(8)$ & - & - & - \\
\hline POS436 209DR-2a & NKR & $0.598(9)$ & $0.160(4)$ & $1.28(4)$ & $0.81(2)$ & $1.0363(8)$ & $1.0031(6)$ & $1.07(3)$ & - & - \\
\hline POS436 215DR-1 & NKR & $0.885(7)$ & $0.234(3)$ & $1.30(2)$ & $0.80(1)$ & $1.043(1)$ & $1.0040(8)$ & $1.09(3)$ & - & - \\
\hline SM01-DR-24-14 & $\mathrm{JM}$ & $7.9(1)$ & $2.08(5)$ & $1.13(3)$ & $0.80(2)$ & $0.9076(6)$ & $0.999(2)$ & $1.01(3)$ & - & - \\
\hline SM01-DR-5-5 & $\mathrm{JM}$ & $6.69(9)$ & $1.77(3)$ & $1.15(2)$ & $0.80(2)$ & $0.9179(6)$ & $1.002(1)$ & $1.16(3)$ & - & - \\
\hline SM01-DR-60-43 & $\mathrm{JM}$ & $6.48(8)$ & $1.71(3)$ & $1.15(2)$ & $0.80(2)$ & $0.9249(6)$ & $1.0020(6)$ & $1.05(3)$ & - & - \\
\hline SM01-DR67-4 & SMR & $4.66(9)$ & $1.42(3)$ & $1.01(3)$ & $0.93(3)$ & $0.9361(9)$ & $1.0042(7)$ & $1.03(3)$ & - & - \\
\hline \multicolumn{11}{|c|}{ Subaerial samples (samples from Maaløe et al., 1986): } \\
\hline JM-192 & $\mathrm{JM}$ & $3.33(4)$ & $0.80(1)$ & $1.04(2)$ & $0.72(1)$ & $0.7499(6)$ & $0.9861(6)$ & $0.99(3)$ & - & - \\
\hline JM-71 & $\mathrm{JM}$ & $4.21(5)$ & $1.11(2)$ & $1.15(3)$ & $0.80(2)$ & $0.9178(7)$ & $1.0009(7)$ & $0.99(3)$ & - & - \\
\hline JM-84 & $\mathrm{JM}$ & $7.24(9)$ & $1.93(3)$ & $1.08(2)$ & $0.81(2)$ & $0.8701(7)$ & - & $1.00(3)$ & - & - \\
\hline JM-84 replicate ${ }^{a}$ & $\mathrm{JM}$ & $6.90(9)$ & $1.84(3)$ & $1.09(2)$ & $0.81(2)$ & $0.8779(6)$ & $0.9993(8)$ & $0.97(3)$ & - & - \\
\hline \multicolumn{11}{|l|}{ Standard analyses: } \\
\hline BCR-2 & & $6.0(1)$ & $1.74(4)$ & $0.99(3)$ & $0.88(3)$ & $0.8784(9)$ & $1.0034(6)$ & $1.00(3)$ & - & - \\
\hline BCR-C & & $5.96(1)$ & $1.712(7)$ & $1.010(5)$ & $0.871(4)$ & $0.8790(9)$ & $1.004(7)$ & $1.00(6)$ & & \\
\hline $\mathrm{W}-2 \mathrm{a}$ & & $2.17(3)$ & $0.50(5)$ & $1.02(10)$ & $0.70(7)$ & 0.7176 & $1.0031(6)$ & $0.99(3)$ & - & - \\
\hline BHVO-2 & & $1.21(2)$ & $0.420(7)$ & $1.04(2)$ & $1.05(2)$ & 1.0929 & $1.0004(5)$ & - & - & - \\
\hline
\end{tabular}

* Values in parentheses indicate $2 \sigma$ analytical uncertainty for the last digit expressed.

** NKR: Northern Kolbeinsey Ridge; JM: Jan Mayen Island; SMR: Southern Mohns Ridge.

${ }^{a}$ Sample JM-84 was replicated using hand-crushed rock chips, to check analytical consistency. Samples JM-192, JM-71, and JM-84 were otherwise analyzed using powder ground in a zirconia shatterbox.

${ }^{\mathrm{b}}\left({ }^{210} \mathrm{~Pb}\right)$ measured by alpha counting of ${ }^{210} \mathrm{Po}$ at the University of Iowa.

${ }^{\mathrm{c}}$ Data are reported using the following decay constant values: $\lambda_{\mathrm{U}-238}=1.551 \times 10^{-10}$ (Jaffey et al., 1971), $\lambda_{\mathrm{Th}-232}=4.948 \times 10^{-11}$ (LeRoux and Glendenin, 1963$)$, $\lambda_{\text {Th-230 }}=9.158 \times 10^{-6}$, (Cheng et al., 2000), $\lambda_{\mathrm{U}-234}=2.826 \times 10^{-6}$ (Cheng et al., 2000).

${ }^{\mathrm{d}}$ Results in italics indicate $\left({ }^{234} \mathrm{U} /{ }^{238} \mathrm{U}\right) \neq 1.000 \pm 0.005$, suggesting effects of weathering or seawater alteration. 
Table 3 Values used for melt modeling calculations in this study.

Variable: Value(s)

Units

Partition coefficients *

$\mathrm{D}_{\mathrm{U}}^{\text {Spinel peridotite/melt a }}$

$2.1 \times 10^{-3}$

$\mathrm{D}_{\mathrm{Th}}$ Spinel peridotite/melt a

$2.2 \times 10^{-3}$

$\mathrm{D}_{\mathrm{U}}^{\text {Garnet peridotite/melt } \mathrm{b}}$

$6.5 \times 10^{-3}$

$\mathrm{D}_{\mathrm{Th}}$ Garnet peridotite/melt $\mathrm{b}$

$4.4 \times 10^{-3}$

$\mathrm{D}_{\mathrm{U}}^{\text {Eclogite/melt c }}$

$1.2 \times 10^{-2}$

$\mathrm{D}_{\mathrm{Th}}{ }^{\text {Eclogite/melt } \mathrm{c}}$

$3.6 \times 10^{-3}$

$\mathrm{D}_{\mathrm{Ra}}{ }^{\text {Bulk rock/melt d }}$

$1 \times 10^{-5}$

Reactive porous flow input parameters for UserCalc (Spiegelman, 2000):

Maximum residual porosity range

$\begin{array}{cl}0.02 \text { to } 1.0 & \% \\ 0.006 \text { to } 7.5 & \mathrm{~m} / \mathrm{yr} .\end{array}$

Solid mantle upwelling rate range

Permeability exponent

$$
2
$$

Pressure gradient

$3.2373 \quad \mathrm{GPa} / \mathrm{km}$

Model accuracy tolerance

$1 \times 10^{-6}$

Initial activities for all nuclides

1.0

Peridotite column length ${ }^{\mathrm{e}}$

100

$\mathrm{km}$

Eclogite column length ${ }^{f}$

75

$\mathrm{km}$

Garnet-spinel peridotite transition pressure

2.5

$\mathrm{GPa}$

Peridotite melt productivity ${ }^{\mathrm{e}}$

5

$\% / \mathrm{GPa}$

Eclogite melt productivity ${ }^{\mathrm{f}}$

15

$\% / \mathrm{GPa}$

Dynamic melting input parameters (after Zou and Zindler, 2000):

Maximum residual porosity range

\begin{tabular}{cl}
0.02 to 1.0 & $\%$ \\
$4 \times 10^{-5}$ to $5 \times 10^{-3}$ & $\mathrm{~kg} / \mathrm{m}^{3} / \mathrm{yr}$. \\
3300 & $\mathrm{~kg} / \mathrm{m}^{3}$ \\
2800 & $\mathrm{~kg} / \mathrm{m}^{3}$ \\
\hline
\end{tabular}

Melting rate range

Residual solid density

Melt density

* Where the partition coefficient $\mathrm{D}_{\mathrm{i}}^{\text {Solid/liquid }}=\mathrm{C}_{\mathrm{i}}^{\text {solid }} / \mathrm{C}_{\mathrm{i}}^{\text {liquid }}$.

${ }^{a}$ Determined using spinel peridotite silicate mineral modes of 20\% clinopyroxene (Cpx), $60 \%$ olivine $(\mathrm{Ol}), 20 \%$ orthopyroxene (Opx); $\mathrm{D}_{\mathrm{U}}{ }^{\text {Cpx/melt }}=0.008, \mathrm{D}_{\mathrm{U}}{ }^{\text {Ol/melt }}=0.00005, \mathrm{D}_{\mathrm{U}}{ }^{\text {Opx/melt }}=0.0024 ; \mathrm{D}_{\mathrm{Th}}{ }^{\text {Cpx/melt }}=0.007 ; \mathrm{D}_{\mathrm{Th}}{ }^{\text {Ol/melt }}=$ $0.00047, \mathrm{D}_{\mathrm{Th}}{ }^{\text {Opx/melt }}=0.0027$ (Salters and Longhi, 1999).

${ }^{\mathrm{b}}$ Determined using garnet peridotite mineral modes of $12 \%$ garnet $(\mathrm{Gt}), 8 \% \mathrm{Cpx}, 59 \% \mathrm{Ol}, 21 \% \mathrm{Opx} ; \mathrm{D}_{\mathrm{U}}{ }^{\mathrm{G} / \mathrm{melt}}=$ $0.038, \mathrm{D}_{\mathrm{U}}{ }^{\text {Cpx/melt }}=0.003, \mathrm{D}_{\mathrm{U}}{ }^{\text {Ol/melt }}=0.00005, \mathrm{D}_{\mathrm{U}}{ }^{\text {Opx/melt }}=0.0078 ; \mathrm{D}_{\mathrm{Th}}{ }^{\text {Gt/melt }}=0.017, \mathrm{D}_{\mathrm{Th}}{ }^{\text {cpx/melt }}=0.004, \mathrm{D}_{\mathrm{Th}}{ }^{\text {Ol/melt }}=$ $0.00047, \mathrm{D}_{\mathrm{Th}}{ }^{\text {opx }}$ /melt $=0.0086$ (Salters et al., 2002).

${ }^{\mathrm{c}}$ Determined using eclogite mineral modes of $40 \% \mathrm{Gt}, 60 \% \mathrm{Cpx} ; \mathrm{D}_{\mathrm{U}}{ }^{\mathrm{G} t / \mathrm{melt}}=0.02405, \mathrm{D}_{\mathrm{U}}{ }^{\mathrm{Cpx} / \mathrm{melt}}=0.0041, \mathrm{D}_{\mathrm{Th}}{ }^{\mathrm{G} t \mathrm{melt}}=$ $0.00415, \mathrm{D}_{\mathrm{Th}}{ }^{\text {Cpx/melt }}=0.0032$ (Pertermann et al., 2004).

${ }^{\mathrm{d}}$ Radium considered to be extremely incompatible in all mantle mineral phases and bulk rocks.

${ }^{\mathrm{e}}$ Garnet peridote melting must begin in the garnet stability field, making a $100 \mathrm{~km}$ melt column reasonable. A constant melt productivity rate is assumed, after Elkins et al. $(2011 ; 2014)$.

${ }^{\mathrm{f}}$ Eclogite melting is expected to initiate considerably deeper than peridotite melting, but due to its higher melt productivities (e.g., Hirschmann and Stolper, 1996; Pertermann and Hirschmann, 2003) will reach 100\% melting after $\sim 75 \mathrm{~km}$ of upwelling (after Elkins et al., 2011; 2014). 